\section{Depositional facies and}

platform architecture of

microbialite-dominated

carbonate reservoirs,

Ediacaran-Cambrian Ara

\section{Group, Sultanate of Oman}

\section{John Grotzinger and Zuwaina Al-Rawahi}

\section{ABSTRACT}

Intrasalt carbonates of the Ediacaran-Cambrian Ara Group constitute a significant reservoir element of the intrasalt "stringer" play in Oman, in which dolomitic carbonates are encased in salt at depths of 3 to $7 \mathrm{~km}$ (1.9 to $4.3 \mathrm{mi}$ ). These reservoir carbonates have significant microbial influences. Although Ara Group reservoirs are mostly latest Precambrian, the models developed here may be applicable to younger microbially dominated carbonate reservoirs in basins of higher salinity when higher organisms are excluded, in lacustrine settings where calcified invertebrates are not a significant source of carbonate, or after periods of mass extinction before faunal recovery. A broad range of carbonate facies provides the context in which to understand the origin of the microbialite-dominated reservoirs developed across both ramp and rimmed shelf profiles. Major facies associations include carbonate-evaporite transition zone, deep ramp and slope, subtidal microbialites, clastic-textured carbonates, and restricted peritidal carbonates. Microbialites are subdivisible into a number of facies that all have significance in terms of understanding environmental history as well as reservoir properties, and that help in predicting the location of reservoir fairways. Microbially influenced facies include shallow subtidal thrombolites with massive clotted textures and very high initial porosities $(>50 \%)$, shallow subtidal pustular laminites with cm-scale variability of lamina morphology, deeper subtidal crinkly laminites that show mm-scale variability of lamina morphology, and intertidal tufted laminates that

Copyright (C2014. The American Association of Petroleum Geologists. All rights reserved.

Manuscript received April 30, 2012; provisional acceptance February 07, 2012; revised manuscript received December 30, 2013; final acceptance February 27, 2014.

DOI: 10.1306/02271412063

\section{AUTHORS}

JOHN GRoTzINGER Division of Geological and Planetary Sciences, California Institute of Technology, Pasadena, California; grotz@gps.caltech.edu

John Grotzinger is a geologist interested in the evolution of surficial environments on Earth and Mars. Field mapping studies are the starting point for more topical laboratory-based studies involving geochemical, geological, and geochronological techniques.

ZUWAINA AL-RAWAHI $\sim$ Petroleum Development Oman, Muscat, Sultanate of Oman; Present Address: Shell UK Limited, London, UK; Zuwaina.Al-Rawahi@Shell.Com.

Zuwaina Al-Rawahi is a senior exploration geologist currently working on New Ventures opportunities in the Europe CIS region. Her main interest is in carbonate sedimentology, in particular understanding reservoir distribution and prediction.

\section{ACKNOWLEDGEMENTS}

We thank the Ministry of Oil and Gas and the Exploration Management of Petroleum Development Oman (PDO) L.L.C. for their permission to publish this paper. We gratefully acknowledge all of the PDO explorers, past and present, which have helped to understand the stringer play. In particular, we thank Joachim Amthor, Jim Beer, Jean-Michel Larroque, Bruce Levell, Gideon Lopez Cardozo, Jeroen Peters, Mark Newall, Joachim Rheinhardt, Hisham Al-Siyabi, Steven van Rossen, and Harry Soek for their significant efforts in helping to develop the models presented here and in supporting the extensive coring program that underpins these models. Jim Beer and Jen Griffes helped with construction of Figure 3. We enjoyed productive and open exchange of ideas with Nigel Cross, Imelda Johnson, Cathy Hollis, Gordon Coy, and Paul Milroy in the core shed. The manuscript was improved by very helpful review provided by Brian Coffey, Mark Longman, Gideon Lopez Cardozo, Jim Markello, and Taury Smith. 
The AAPG Editor thanks the following reviewers for their work on this paper: Brian P. Coffey, Mark W. Longman, and James R. Markello. show mm- to cm-scale tufted textures. Other reservoir facies are more conventional grainy carbonates including ripple cross-stratified grainstone-packstone, hummocky cross-stratified grainstone-packstone, flat pebble conglomerate, ooid and intraclast grainstone-packstone, and Cloudina grainstone-packstone. These facies are almost invariably dolomitized and all have moderate to excellent reservoir quality. These facies comprise carbonate platforms, broken up during salt tectonics, that range up to $160 \mathrm{~m}(525 \mathrm{ft})$ in thickness and extended laterally, prior to halokinesis, for tens to over $50 \mathrm{~km}$ (31 mi). The distribution of reservoir facies follows sequence stratigraphic predictions, with microbialites occurring in every accommodation profile. Late highstand and early transgressive systems tracts favor greater lateral extent of thrombolite build-ups, whereas later transgressive to early highstand system tracts favor greater lateral discontinuity and compartmentalization of buildup reservoir facies. Pustular laminites occur in close association with thrombolite buildups but form laterally extensive sheets in late transgressive to late highstand periods. Crinkly laminites form during late transgressive to early highstand systems tracts and may represent maximum flooding intervals when the flux of carbonate sediment was greatly reduced allowing pelagically derived organics to accumulate.

\section{INTRODUCTION}

Microbialite-dominated carbonate platforms of the Ara Group constitute an extraordinary oil and gas play, the geologically oldest known that is commercially viable. The platforms, colloquially known as stringers, are encased within salt of the South Oman salt basin (SOSB) and form large floating rafts suspended in diapirically deformed halite.

By several measures, the stringer play is unconventional. The reservoirs are commonly over-pressured and consist of porous dolomites encased in salt at depths of 3 to $7 \mathrm{~km}$ (1.9 to $4.3 \mathrm{mi}$ ). Seismic resolution is greatly diminished due to surface static effects and attenuation within the salt. Despite relatively simple (and limited) diagenesis involving carbonate phases of cementation, plugging by halite is complex and so far unpredictable. Finally, the distribution of porous shallow-water facies, particularly those of microbial origin, is critically important to building predictive reservoir models (Al-Siyabi, 2005). This latter issue, the distribution of primary facies, is the focus of this paper. This is perhaps the most important factor in predicting the locations of reservoir fairways for all of the Ara Group carbonate platforms.

In more conventional carbonate plays, reservoir models are constructed based on information provided by rock properties 
obtained from available wells in the field of interest. However, where these data are sparse, interpolation and extrapolation of facies belts can be guided by data derived from other case studies of fields involving rocks of similar geologic age (Roehl and Choquette, 1985), or on scaling properties imported from distributions observed in modern analogs (Harris, 2010). However, because of the antiquity of the Ara Group rocks, there are no other case studies based on existing fields or production analogs from which to draw. In addition, use of modern analogs is greatly limited because of their dominance by metazoan and metaphyte-based sediment production systems.

Thus, for the Ara Group, the mapping and modeling of reservoir fairways have depended exclusively on data derived from exploration, development, and production wells drilled through the Ara Group. For over a decade, a significant core-based data set for the Ara Group has been acquired that allows identification of unusual facies types, their spatial distributions, pore systems, and diagenetic history. Several of the microbially dominated facies have no close modern analogs; however, it has been helpful to guide interpretation using an outcrop analog based on age-equivalent facies in the Nama Group of Namibia. The Nama Group has been particularly valuable in showing the great lateral extent of microbial and associated grainstone facies (Adams et al., 2004, 2005).

Here, we review the geologic and stratigraphic setting of the Ara Group, describe the key facies that form carbonate reservoirs, their lateral and vertical extent, and what factors control their distribution. The key point that emerges from over a decade of dedicated study is that microbial facies, and their associated clastic-textured carbonates, can form reservoirs of significant lateral extent in both shallow and deeper water settings.

\section{GEOLOGIC SETTING}

\section{Regional Stratigraphy}

The Huqf Supergroup in the Sultanate of Oman represents a superb record of Ediacaran to earliest Cambrian Earth history (Allen, 2007; Bowring et al.,
2007). The Huqf Supergroup is well exposed in central and northern Oman, including the Huqf area and the Oman Mountains (Gorin et al., 1982; Mattes and Morris, 1990; Wright et al., 1990) in the Mirbat area of southern Oman (Kellerhals and Matter, 2003; Mercolli et al., 2006) (Figure 1), and is intercepted in numerous wells in the SOSB (Al-Siyabi, 2005). The Huqf Supergroup is subdivided into three groups (Gorin et al., 1982; Mattes and Morris, 1990; Wright et al., 1990; Schröder et al., 2005; Osburn et al., 2014) (Figure 2). The lowermost unit is the Abu Mahara Group, which consists of glacial clastics. This is overlain by the Nafun Group, which is divisible into the Hadash Formation (cap-carbonate) and Masirah Bay Formation (shelf clastics). The next overlying units are the Khufai Formation (restricted, prograding carbonate ramp), Shuram Formation (storm-dominated shelf clastics and carbonates) and Buah Formation (storm-dominated, prograding carbonate ramp. Finally, the Huqf Supergroup is capped by the Ara Group, which consists of several carbonate platforms interlayered with evaporites. In general, the outcrops constrain the Abu Mahara and Nafun Groups, whereas cores, well logs, and seismic data provide constraints on the thickness and distribution of the Ara Group. In outcrops of the Oman Mountains, the volcaniclastic Fara Formation overlies the Buah Formation and is generally considered time equivalent to the Ara Group. Strata of possible Ediacaran-Cambrian boundary age are known only from subsurface data (Amthor et al., 2003; Schröder et al., 2005; Fike and Grotzinger, 2008). A few key wells intersected both the Abu Mahara and Nafun Groups on structural highs, thus providing ties between the surface exposures and the subsurface (Mattes and Morris, 1990; Cozzi et al., 2004; Fike and Grotzinger, 2008). The Huqf Supergroup preserves several distinct stages of basin development, probably associated with different subsidence mechanisms.

\section{Tectonics}

The Abu Mahara Group was deposited within localized fault-bounded basins, whereas the overlying Nafun Group is laterally extensive, reflecting broad, regional subsidence associated with either passive 
Figure 1. Simplified geological map showing outline of the upper Ediacaran to lower Cambrian salt basins in the interior of the Sultanate of Oman. Within the South Oman salt basin (SOSB), the Southern Carbonate Domain is separated from the Northern Carbonate Domain by a deep basin, the Athel trough. The platforms discussed in this paper all occur in the Southern Carbonate Domain. The SOSB is bounded to the east by the Eastern Flank, a long-lived high, and to the west by the Western Margin, a deformation front that was active during Ara deposition and that shed clastics into the western part of the basin. Modified after Al-Siyabi, 2005.

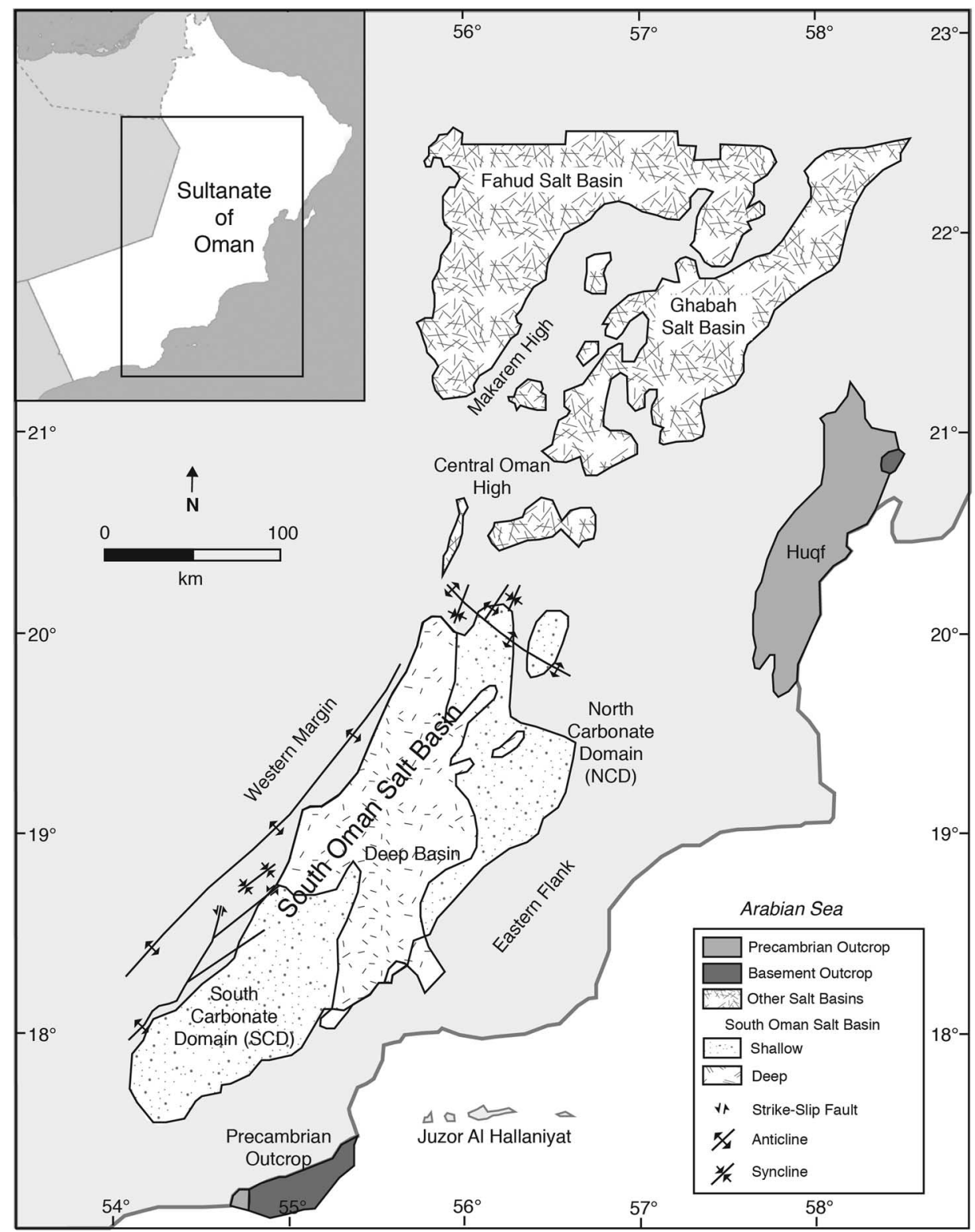

thermal cooling (Allen, 2007) or dynamic depression of the lithosphere (Grotzinger et al., 2002). The Nafun Group-Ara Group boundary marks a shift from this regional subsidence to a tectonic style marked by uplift of large basement blocks that segmented the broader basin into several fault-bounded subbasins (Immerz et al., 2000; Allen, 2007; Bowring et al., 2007). The Ara Group depositional patterns reflect segmentation of the Nafun basin into three smaller scale basins within the interior of Oman. This segmentation began at ca. 550 to $548 \mathrm{Ma}$, and was accompanied by a shift to a more arid climate, accumulation of salts and carbonates, and bimodal volcanism (Bowring et al., 2007). These basins include the SOSB, the Ghaba salt basin, and the Fahud salt basin (Figure 1). Seismic data indicate that the western margins of these basins are delineated by structurally complex transpressional deformation fronts (Loosveld et al., 1996) of Ara age (late Ediacaran to earliest Cambrian). An upper age limit for deformation is provided by sediments that contain upper Cambrian trilobites, derived from uplift and erosion of the western margin. A significant clastic wedge, represented by the Nimr Group, is derived from unroofing of a western deformation front (Western Margin, Figure 1). Clastic sediments 


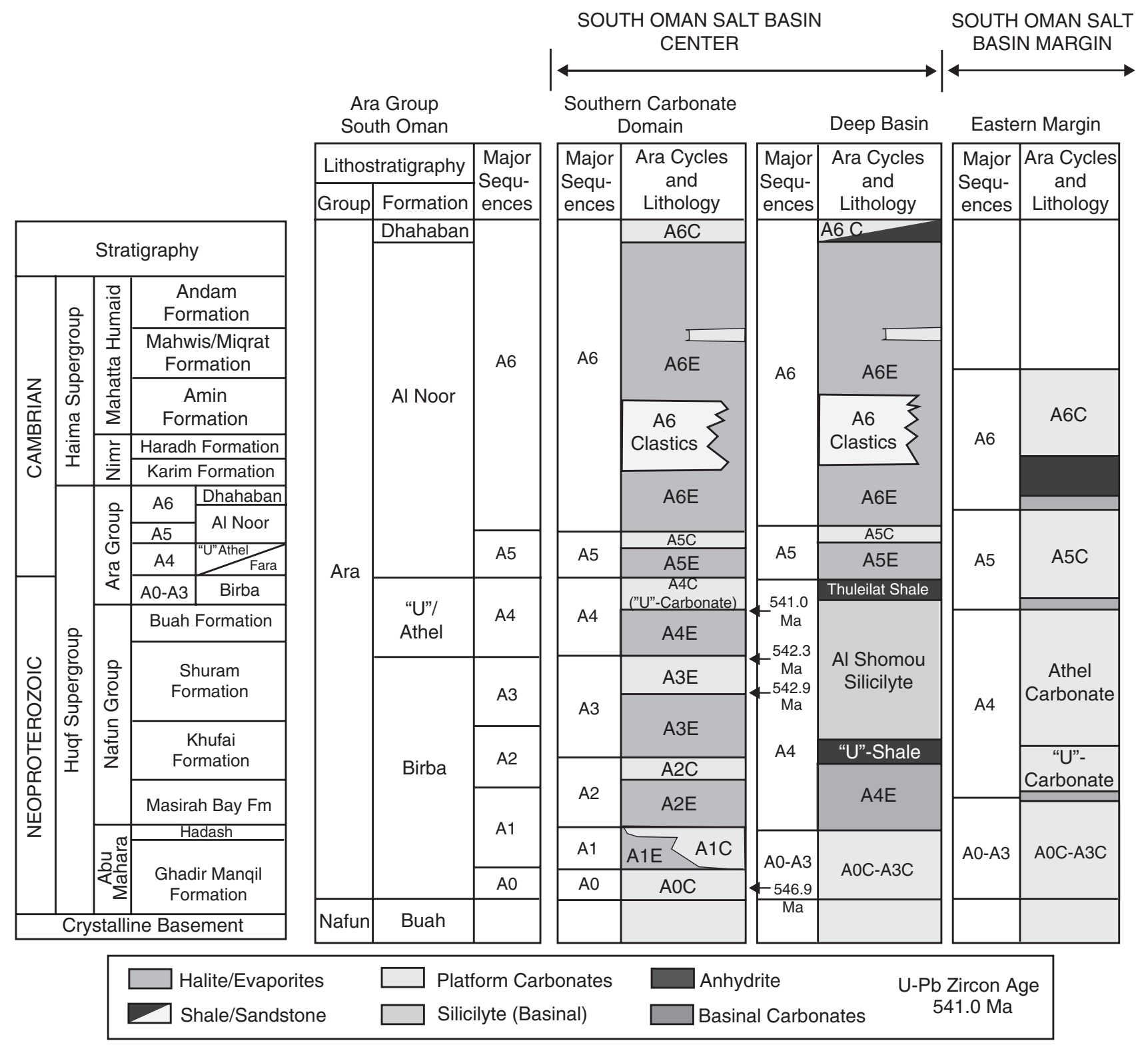

Figure 2. Generalized stratigraphy for upper Cryogenian to upper Cambrian Huqf Supergroup, with emphasis on the Ara Group of the SOSB. Note spatially dependent variation in carbonate-evaporite cycles across the Southern Carbonate Domain, Deep Basin (Athel trough), and into the Eastern Flank. Modified after Al-Siyabi, (2005) and Bowring et al. (2007).

of the uppermost Ara Group signal the onset of this event. In contrast, the eastern margins of the salt basins are characterized by onlap and thinning of basin strata onto a structural high located close to the modern-day east coast of Oman. Within the three salt basins, further segmentation occurred, with localized subsidence related to basement-involved block faulting. Within the SOSB the uplifted blocks became sites of carbonate deposition, and downfaulted blocks were overlain with black shale and silica-rich shales ("silicilyte") (Amthor et al., 2005). Evaporites blanketed both basins and uplifted blocks.

Subsidence of the Ara Group is thought to be analogous to the Laramide orogeny of the western United States, or the Bolivian segment of the Andes where flat-slab subduction occurred. Retro-arc uplift and desiccation may have helped produce the Ara evaporite deposits, and the numerous ash beds of the Ara Group are likely airfall equivalents of contemporaneous arc magmatism. Thick sequences of felsic 
volcanic rocks, such as those represented by the Fara Formation (Oman Mountains) and in the subsurface (Ghaba salt basin), are all broadly consistent with subduction-related melting of the crust in a retro-arc setting (Grotzinger et al., 2002).

\section{Hydrocarbon Source}

Interstratified carbonates and evaporites of the Ara Group accumulated within these subbasins creating an ideal geologic setting for the generation, trapping and long-term preservation of hydrocarbons (Al-Siyabi, 2005). The SOSB has long been recognized as a major hydrocarbon province (Morton, 1959), although it was not clear until the mid-1970s that the dominant source rock is terminal Proterozoic. Subsequent work demonstrated that this source rock charged not only Proterozoic reservoirs, but also Paleozoic and Mesozoic reservoirs (Al-Marjeby and Nash, 1986). Recent biomarker studies point to extensive microbial sources for Ara Group hydrocarbons (Grosjean et al., 2009). Older Huqf rocks of the Abu Mahara Group contain sponge-derived biomarkers (Love et al., 2009).

\section{South Oman Salt Basin}

As discussed above, the three salt basins in the subsurface of Oman show evidence for structural partitioning into subbasins. This is shown clearly for the SOSB with its western (Western Margin) and eastern (Eastern Flank) boundaries. Within these boundaries, it contains a fault-bounded depression known as the "Athel trough," which is flanked by southern and northern domains where carbonate platforms developed.

\section{Southern Domain Carbonates}

The Southern Domain is the region in which carbonate stringers have been extensively explored leading to significant commercial success (Al-Siyabi, 2005). The stringers are stacked, salt-bounded carbonate platforms that have been broken apart due to halokinesis. They tend to cluster (Figure 3 ) in two groups known as the Birba cluster and the Harweel cluster. Only rare shale occurs in the southern domain and no silicilyte (described in later section on "Athel
Trough") has ever been observed in the Southern Domain, indicating that the carbonates are likely localized on one or more regional highs.

\section{Athel Trough}

The Athel trough was the site of a deep basin with potential relief of more than $200 \mathrm{~m}(656 \mathrm{ft})$ in which black shales and a unique laminated chert, the Al Shomou silicilyte, accumulated (Amthor et al., 2005). These rocks are organic rich, and known to have charged both the silicilyte as well as some adjacent carbonate platform reservoirs. These facies are interpreted to have formed in a stratified anoxic basin formed below wave base (Amthor et al., 2005) and are bounded by thick halite sequences containing rare carbonates. The trough was formed by transtensional faulting, though its western boundary also coincides with the depositional edge of a rimmed carbonate platform of early Ara time of deposition.

\section{Northern Domain Carbonates}

Northern Domain carbonates are similarly distributed as stringers throughout the salt; however this domain has received far less drilling (Al-Siyabi, 2005). What few wells were drilled have not been successful, and this has discouraged further exploration. In addition, the carbonates that were drilled did not show development of thick shallow-water platform facies in contrast to the Southern Domain. Northern Domain carbonates are interstratified with thick salt deposits and lack shale-silicilyte deposits.

\section{ARA GROUP STRATIGRAPHY}

The Ara Group contains at least six tectono-eustatic evaporite-carbonate cycles (Forbes et al., 2010). Cyclicity reflects changes in water depth and water salinity of the depositional basin. The carbonates are marine in origin and mostly of normal salinity as indicated by the presence of Cloudina and Namacalathus, two Ediacaran index fossils (Amthor et al., 2003). Toward the Eastern Flank of the SOSB, evaporites pinch out (or were dissolved beneath the sub-Ordovician unconformity); there, time-equivalent rocks consist of stacked carbonates. Fine siliciclastic deposits interfinger near the western 


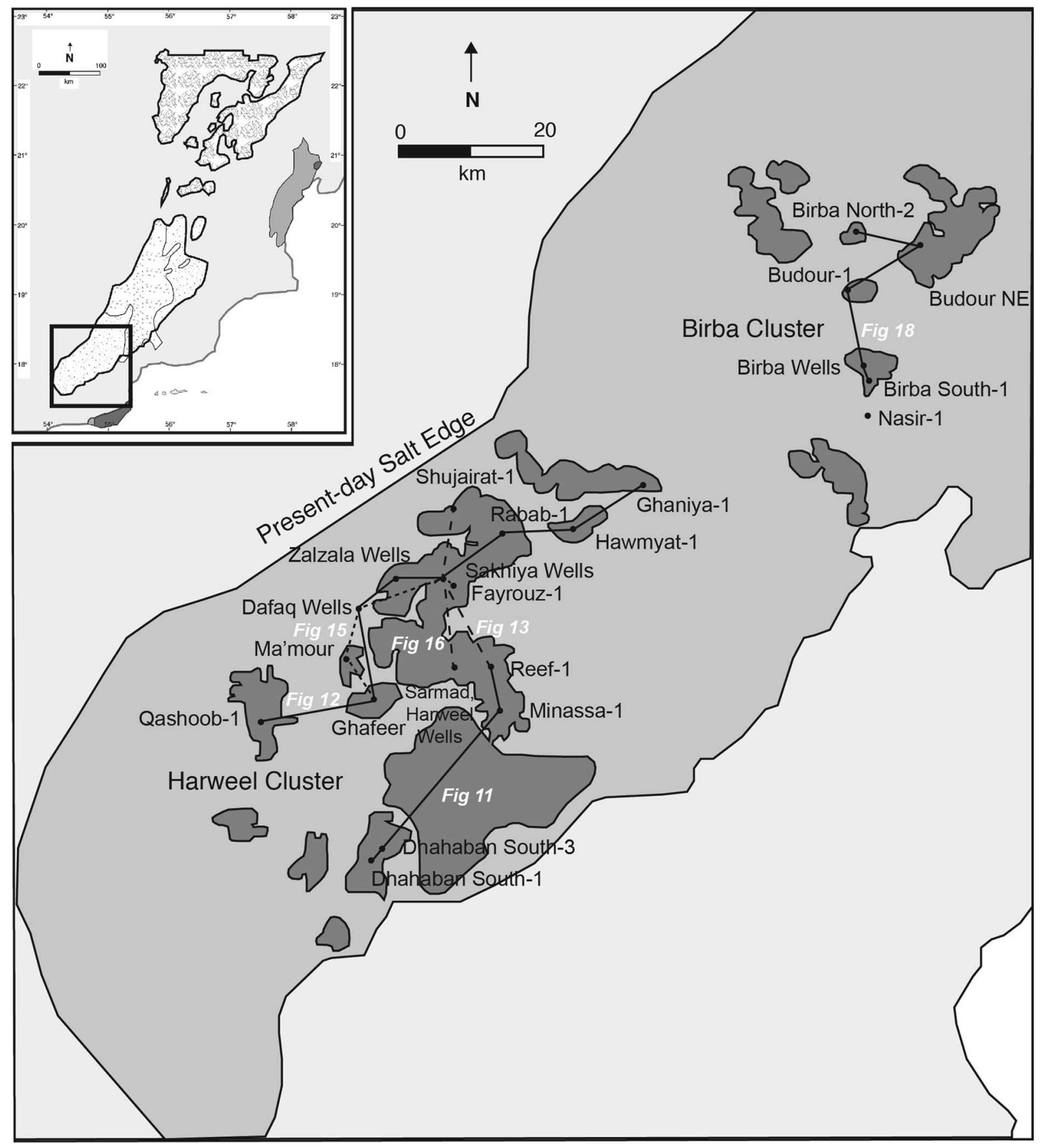

Figure 3. Distribution of stringer prospects in Southern Carbonate Domain. Note clustering in two groups: the southern Harweel cluster and northern Birba cluster. Each prospect represents a broken piece of a carbonate platform floating in salt. Breakup of these platforms occurred during halokinesis and can affect A1-A6 age platforms. Location of stratigraphic cross sections shown in Figures $11,12,13,15,16$, and 18 is plotted.

limit of the Ara Group, derived from the uplifting Western Margin; the youngest of these clastics prograded eastward over the top of the Ara Group (Mattes and Morris, 1990; Bowring et al., 2007; Forbes et al., 2010) (Figure 4).
The onset of rapid differential subsidence created accommodation for the oldest Ara Group carbonates to be deposited. More rapid subsidence in the Athel trough created the conditions leading to deposition of the Al Shomou silicilyte. The lower unit of each 




Figure 4. Simplied cross section of the SOSB at the latitude of the Birba cluster, Southern Carbonate Domain. Note the deflection of the Nafun Group-Ara Group contact (top of Buah Formation) to the west demonstrating strong subsidence due to crustal loading associated with convergence along the Western Deformation Front. Deposition of the siliciclastic Haima Supergroup caused diapirism of the salt, resulting in breakup of intrasalt carbonate platforms. Modified after Al-Siyabi (2005).

cycle is formed by evaporites that precipitated during basin restriction and commonly contain the characteristic succession anhydrite-halite-anhydrite (Schröder et al., 2003). Periods of extreme restriction led to precipitation of potassium salts. Overlying carbonates represent platform carbonates deposited under conditions of normal marine salinity (Mattes and Morris, 1990).

The Ara Group is subdivided into five formations (Figure 2). In ascending stratigraphic order they are the Birba, "U", Athel, Al Noor, and Dhahaban formations (Forbes et al., 2010). These lithostratigraphic subdivisions collectively capture at least six third-order evaporite-carbonate cycles, designated A0-A6, that were established for the SOSB. Volcanic ash beds within several of the cycles contain zircons that yield $\mathrm{U}-\mathrm{Pb}$ ages for the middle of the $\mathrm{A} 0$ carbonate (546.72 Ma $\pm 0.21 \mathrm{~m} . \mathrm{y}$.$) , base and top of$ the A3 carbonate $(542.90 \mathrm{Ma} \pm 0.12 \mathrm{~m} . \mathrm{y}$. and $542.33 \mathrm{Ma} \pm 0.12 \mathrm{~m} . \mathrm{y}$, , respectively), and base of the A4 carbonate (541.00 Ma \pm 0.13 m.y.) (Bowring et al., 2007). Bowring et al. (2007) used these four ages to constrain the average duration of each evaporite-carbonate cycle (1.2-1.3 m.y.), in addition to directly constraining the duration of the $\mathrm{A} 3$ carbonate (0.3-0.8 m.y.).

The Birba Formation comprises carbonates and evaporites of the A0-A3 cycles. Carbonate units vary in thickness from 50 to $150 \mathrm{~m}$ (164 to $492 \mathrm{ft}$ ); depositional thicknesses of interstratified evaporites are difficult to estimate due to halokinesis, but sulfate deposits range from 0 to $30 \mathrm{~m}$ ( 0 to $98 \mathrm{ft}$ ) and halite deposits are tens to hundreds of meters. The basal Birba member (A0) is distinct and contains a number of shale and volcanic tuff-rich carbonates; these form excellent markers for regional correlation of the Ara base.

The "U" Formation comprises the A4 cycle including its evaporites, thin basal shale, and overlying carbonate platform that is up to $80 \mathrm{~m}(262 \mathrm{ft})$ in thickness. The formation derives its name from a distinctive high gamma-ray log expression that reflects high uranium content (Mattes and Morris, 1990; Amthor et al., 2003; Forbes et al., 2010). In addition, the "U" Formation has a distinctive negative carbon isotopic excursion of up to -5 per mil that distinguishes these rocks. However, both of these 
signals are well developed in the northern half of the Southern Domain. In the Athel Trough, the deeper water equivalents of the "U" Formation form the Athel Formation. The "U" and laterally equivalent Athel formations are bounded between lowstand evaporites of the A4 and A5 cycles.

The Al Noor and Dhahaban formations (A5 and A6 cycles) include evaporites, siliciclastics, and carbonates. Prolonged periods of basin restriction generated halite deposits in excess of 1,000 $\mathrm{m}(>3,281 \mathrm{ft})$ with intercalated potassium salts. These facies interfinger westward with fine eolian to distal fluvial siliciclastics. Some of the carbonates include shallow-water thrombolite pinnacle reefs that are up to several tens of meters thick. The Dhahaban Formation is a regionally extensive carbonate deposit that caps the Ara Group. These carbonates are extensively brecciated and may represent the residue formed during dissolution of the salt at the base of the Haima Supergroup, which overlies the Ara and is a basin-filling fluvial-eolian sandstone.

\section{Sequence Stratigraphic Context of Evaporites}

One important aspect of the Ara evaporites is that they do not represent classic lowstands, spatially separated from the highstand carbonates and timeequivalent to exposure surfaces capping the carbonates (cf. Sarg, 2001). The Ara evaporites do not occur as basin-filling wedges onlapping basin margin carbonates, but rather blanket the isolated carbonate platforms and are deposited on top of the highstand carbonates. This provides top and base seals for the hydrocarbons contained within each of the carbonate platforms. Numerous cores through the carbonateevaporite transition demonstrate that the platform tops were generally not exposed and instead show an abrupt shallowing followed by a transition in depositional mineralogy from carbonates to sulfates. In some cases evaporites formed of carbonate were precipitated leaving distinct travertine-like deposits at the contact (Pope et al., 1999; Pope and Grotzinger, 2001).

Seismic, core, and log data indicate that Ara carbonates formed isolated platforms, localized mostly within the center of the SOSB, not along its margins (Figure 5). The apparent paradox is that lowstand evaporites occur stratigraphically on the tops of highstand carbonate platforms. Resolution of this paradox requires that evaporite deposition occur during tectonic subsidence, and for sufficient duration so that lowstand evaporites could fill and overlap topography created by earlier highstand carbonates (Amthor et al., 2002). This is supported by geochronologic data (Bowring et al., 2007), which indicate that (at least in one case) an evaporite deposit (A4) accumulated over a much longer period (duration of 1.1 to 1.6 m.y.) than the subjacent carbonate platform (A3; duration of 0.3 to 0.8 m.y.).

The exceptions to this scenario are the carbonates that formed along the basin margin represented by the eastern flank. However, these carbonates lack intervening evaporites, and their spatial isolation from the Ara evaporites is better explained by the classic lowstand model (Sarg, 2001).

\section{Buah-Birba Transition}

The initiation of Ara deposition was coincident with regional tectonism. Volcanic deposits, essentially unknown in the Nafun Group, appear abruptly in basal strata of the Birba Formation (A0). Volcanics in the Ara are mostly felsic tuffs less than $10-15 \mathrm{~cm}$ (<3.9-5.9 in.) thick. These tuffs may have derived from eruptions originating in a caldera observed in the Ghaba salt basin of north Oman. Mafic volcanism is rare: a single occurrence of basaltic spherulitic tuff just above the A2 carbonate in the southern part of the Southern Domain is at least several meters thick. The spherules represent magmatic melt droplets ejected from a neighboring volcanic vent, no more than a few $\mathrm{km}$ distant.

Seismic data indicate a regional angular unconformity at the base of the Ara Group, indicating tilting of older strata (Forbes et al., 2010). The unconformity is overlain by A0 strata. Recent sulfur isotope chemostratigraphic data (Fike, 2007; Fike and Grotzinger, 2008) indicate that the Ara Group (A0-A6) has uniformly strongly positive values of $>35$ per mil $\delta^{34} \mathrm{~S}$, whereas older strata of the Nafun Group are uniformly $<25$ per mil $\delta^{34} \mathrm{~S}$. This change approximately coincides with this tectonic unconformity and therefore makes a useful marker for delineating Nafun versus Ara strata for which seismic and well logs are ambiguous. In addition, dip-meter $\operatorname{logs}$ show 
Northeast

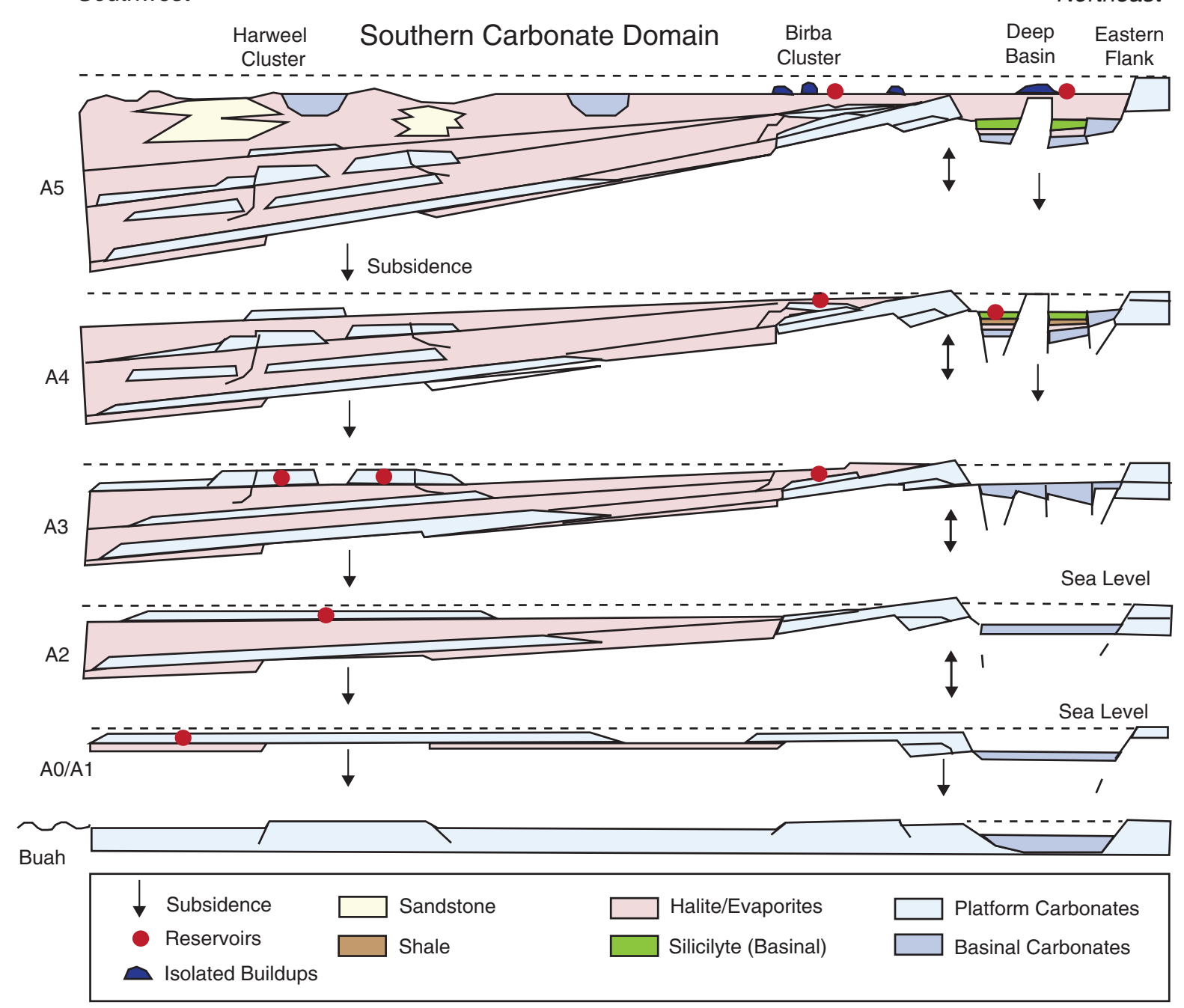

Figure 5. Tectono-stratigraphic development of Ara platforms. The platforms developed during longer term highstand deposition, followed by longer term lowstand evaporite deposition. The deposition of lowstand salt across the top of the highstand platforms provides evidence for strong subsidence during evaporite deposition leading to blanketing of platform tops by salt. Probably, this was driven by convergence along the Western Deformation Front. Note that younger reservoirs step progressively eastward, as deeper water facies occur only in younger carbonates in the southwestern Harweel cluster. In addition, older platforms are more laterally continuous, possibly because they are closer to the base of the salt and experience less strain. Modified after Al-Siyabi (2005).

significant changes in dip at the boundary providing evidence of tectonic rotation (Forbes et al., 2010).

In the Huqf outcrop area some carbonate platform rocks overlie the Buah Formation (youngest Nafun Group) that have evidence of restricted evaporitic facies (Gold, 2010; Bergmann et al., 2012; Bergmann, 2013). In general, however, their facies do not compare well with what is observed in the subsurface (see next section, Ara Carbonate Facies), and their sulfur isotope composition indicates they predate the basal Birba (Fike, 2007; Fike and
Grotzinger, 2008). These rocks may well represent a post-Nafun, but pre-Ara, sequence that is developed on the Central Oman High, a major structure that separates the SOSB from Ghaba Salt Basin.

\section{ARA CARBONATE FACIES}

The carbonate fraction of each Ara cycle represents an individual carbonate platform of significant thickness, with well-developed shallow-water reservoir facies. These carbonate stringers exhibit platform-to-basin 
differentiation expressed as both ramps and rimmed shelves. Consequently, there exists a range of facies that represent these spatially dependent morphologic gradients, in addition to a range of facies that represent the temporally dependent environmental transition from evaporites to carbonates and vice versa. Finally, not all facies occur in all carbonate platforms; some are particular to certain platforms, and particular to the Birba versus the Harweel clusters.

One fundamentally important observation is that almost all Ara carbonate facies are laminated. In a world where bioturbation was absent or very rare, this is the hallmark of Precambrian carbonates in general (Grotzinger, 1989; Grotzinger and James, 2000), and one common point of confusion can arise in mistaking deeper water laminated microbialites, which are rare or absent in Phanerozoic carbonates, with tidalflat microbialites, the normal site of occurrence in Phanerozoic rocks and modern environments. Thus, it becomes essential to evaluate some of the more subtle features of all these laminites in attempting to resolve depositional environments.

We will begin with description of the facies that record the transition from evaporites to carbonates.

\section{Carbonate-Evaporite Transition Facies Association (CET)}

\section{Description}

The CET facies association includes four facies: halite, anhydrite, anhydrite-dolomite rhythmites, and breccias (Figure 6). None have important reservoir properties.

As freshening of the basin occurred, each Ara cycle recorded the transition from halite to a varying thickness of sulfate (currently anhydrite) to carbonates. Halites are universally recrystallized due to halokinesis and lack evidence of primary bedding (Figure 6A). In general, the contact between halite and anhydrite is abrupt (Figure 6A). Anhydrites are better preserved, sometimes preserving primary textures such as chevron structure indicative of replaced selenitic gypsum. In other cases, the anhydrite shows a nodular texture, suggesting growth and recrystallization of displacive gypsum crystals (Figure 6B). Anhydrites may be interbedded with dolomites, sometimes with high siliciclastic content and brecciated textures, suggestive of salt dissolution and bedding collapse.
Upward in the CET, units formed of anhydritedolomite rhythmites are common and characterized by alternations of anhydrite and dolomite mudstone. These units are 2-11 m (6.6-36 ft) thick. Laminae that define rhythmites are typically less than $1 \mathrm{~mm}(<0.04$ in.) in thickness and have very even lamina boundaries. The very fine scale and evenness of lamination is a distinctive attribute of this facies (Figure 6C).

Rhythmite-bearing units may be overlain by units of stratiform breccia, on the order of 10 to $25 \mathrm{~m}$ (33 to $82 \mathrm{ft}$ ) thick. These breccias are known to occur only in the A2 and A3 carbonates. The breccias generally consist of poorly sorted $\mathrm{cm}$-scale fragments of massive dolomite mudstone, massive anhydrite, and anhydrite-dolomite rhythmite in a matrix of dolomite mudstone (Figure 6D). Fabrics are generally clast supported. However, the breccias can also be organized into upward-fining deposits that show clear evidence for mobilization and transport as fragmental sediments (Figure 6E). These mobilized deposits can be matrix supported; however, other examples show evidence of traction transport and development of lamination. These deposits range in thickness from a few $\mathrm{cm}$ up to a few tens of $\mathrm{cm}$.

\section{Interpretation}

The transition from halite to sulfate to carbonate deposits represents a classic freshening of the basin associated with marine flooding (Schröder et al., 2003). Growth of former selenite crystals indicates precipitation within shallow brine pools that covered the floor of the SOSB. The concentration of insoluble siliciclastic detritus near the sulfate-carbonate boundary may reflect submarine dissolution of evaporites by lower salinity marine waters. The presence of anhydrite-carbonate rhythmites is interpreted to indicate daily or seasonal variations in salinity, but in a fully subaqueous setting where sulfate and carbonate crystals formed in the water column and then settled to the sea floor as a cumulate deposit, similar to the Permian Castile Formation (cf. Anderson et al., 1972).

The origin of breccias is less certain, with several possible interpretations. They could represent dissolution collapse breccias and, given their position within the CET, it is possible that a final unit of halite or sulfate was deposited and then dissolved following burial and introduction of meteoric fluids (J. Warren, 




Figure 6. Evaporite facies and carbonate-evaporite transition zone facies. All scale ticks are $1 \mathrm{~cm}(0.4 \mathrm{in}$.). (A) Recrystallized halite passes upward into crudely stratified anhydrite with halite lenses (broken core has white fill along fracture near contact). Minassa-1, $3455.2 \mathrm{~m}$ $(11,336 \mathrm{ft})$ depth. (B) Nodular anhydrite overlain by anhydrite breccia-conglomerate in dolomite mudstone matrix. This facies transition

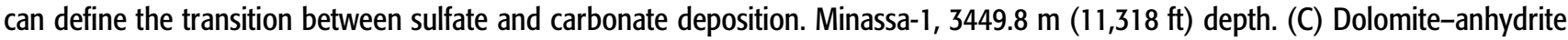
rhythmites. Note mm-scale, planar lamination. Minassa-1, $3447.4 \mathrm{~m}$ (11,310 ft) depth. (D) Massive anhydrite-dolomite breccia. Clasts

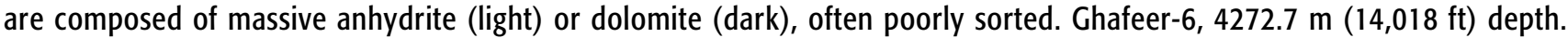
(E) Stratified anhydrite-dolomite breccia. Note normal grading of bed. Largest clasts are composed of dolomite-anhydrite rhythmite. Ghafeer-2, $4194.7 \mathrm{~m}(14,090 \mathrm{ft})$ depth. 
2009, personal communication). Indeed, the lateral persistence of these units would suggest that as well. However, sedimentologic observations contradict the predictions of stratigraphic geometry. Collapse alone, by dissolution, would not explain the presence of fine sediment matrix, and the absence of vuggy porosity and/or void-filling cements. Nor would it explain the lack of dissolution features present in the evaporites that remain. Instead, the presence of the graded beds-intercalated within zones of more massive, clast-rich breccia-suggests that they originated at least in part as sediment gravity flows, likely of subaqueous origin. We suggest a hybrid origin: As transgression and sediment deposition occurred on top of the previously formed halite deposits in which initial halokinesis may have produced local slopes on an otherwise flat surface, leading to the sliding of sulfates and associated carbonates. Alternatively, this process might also have been induced by tectonic processes including local uplift and associated seismicity, which could have triggered liquefaction of poorly consolidated evaporitic sediments. The point is that collapse of evaporites may have occurred; however, it seems to have done this in the presence of at least local slopes, where sediments became mobilized to form sediment gravity flows.

\section{Deep Ramp and Slope Facies Association (DRS)}

\section{Description}

The DRS facies association includes five facies: finely laminated mudstone, massive mudstone, nodular mudstone, crinkly laminated mudstone, and allodapic breccias. All facies are carbonates; however, the degree of dolomitization varies, and most are limestones. In general, these facies have poor reservoir quality, but with one important exception: the crinkly laminite facies, if dolomitized early, can have excellent porosity and permeability.

Finely laminated mudstones typically show fine, even lamination on the scale of $1 \mathrm{~mm}$ (0.04 in.) or less, expressed by alternation of lighter versus darker gray mudstone (Figure 7A). Boundaries of laminae are very even, showing limited undulation. They form monotonous beds up to several meters thick that are punctuated only by occasional thin beds of massive mudstone (Figure 7A). The finely laminated mudstones show small, compaction-related fault displacements of a few $\mathrm{mm}$ or $\mathrm{cm}$.

Massive mudstones form thin to medium-thick beds (Figure 7A) that are interspersed with the other facies of the DRS facies association. Their lack of porosity and permeability cause reservoir deterioration where they increase in abundance relative to productive reservoir facies, such as the crinkly laminites discussed subsequently.

Nodular mudstones are formed of alternating light-toned mudstones that form nodular fabrics within a background of darker toned mudstones. The light-dark couplets range in thickness from a centimeter ( 0.4 in.) (Figure $7 \mathrm{~B})$ up to $5 \mathrm{~cm}$ ( 2 in.) (Figure $7 \mathrm{C}$ ) and form beds up to 3 to $5 \mathrm{~m}$ (9.8-16.4 ft) thick.

Crinkly laminites are superficially similar to finely laminated mudstones in that both facies exhibit mm-scale lamination of mudstone. Dark organic-rich laminae alternate with light, organic-poor laminae to form couplets (Figure 7D). However, the crinkly laminites have irregular lamina boundaries at the scale of the thickness of the laminae themselves. The crinkly appearance results from dark laminae that infill microtopography created by the light laminae; the basal contacts of light laminae are generally much smoother than the upper contacts. Where dolomitized, light laminae have a well-developed vuggy pin point and intercrystalline pore system with high porosity $(\sim 10 \%)$ and moderate permeability $(<120 \mathrm{mD})$ (Schröder et al., 2005). However, if they are not dolomitized then, later aggrading neomorphism tends to form large calcite crystals (Figure 7E) that destroy porosity.

Breccias in this facies association are typically coarse, with blocks of shelf-derived facies of at least $20 \mathrm{~cm}$ (7.9 in.) in width (Figure 7F), forming beds up to several meters in thickness. Blocks consist of thrombolite, cross-stratified peloidal grainstone-packstone, microbialaminite, and massive dolomite. In some cases, blocks are overturned with digitate thrombolite growth structures pointing downward (Figure 7F). The breccia blocks are associated with finer grained beds, showing normal grading of grain size suggestive of sediment gravity flows. 


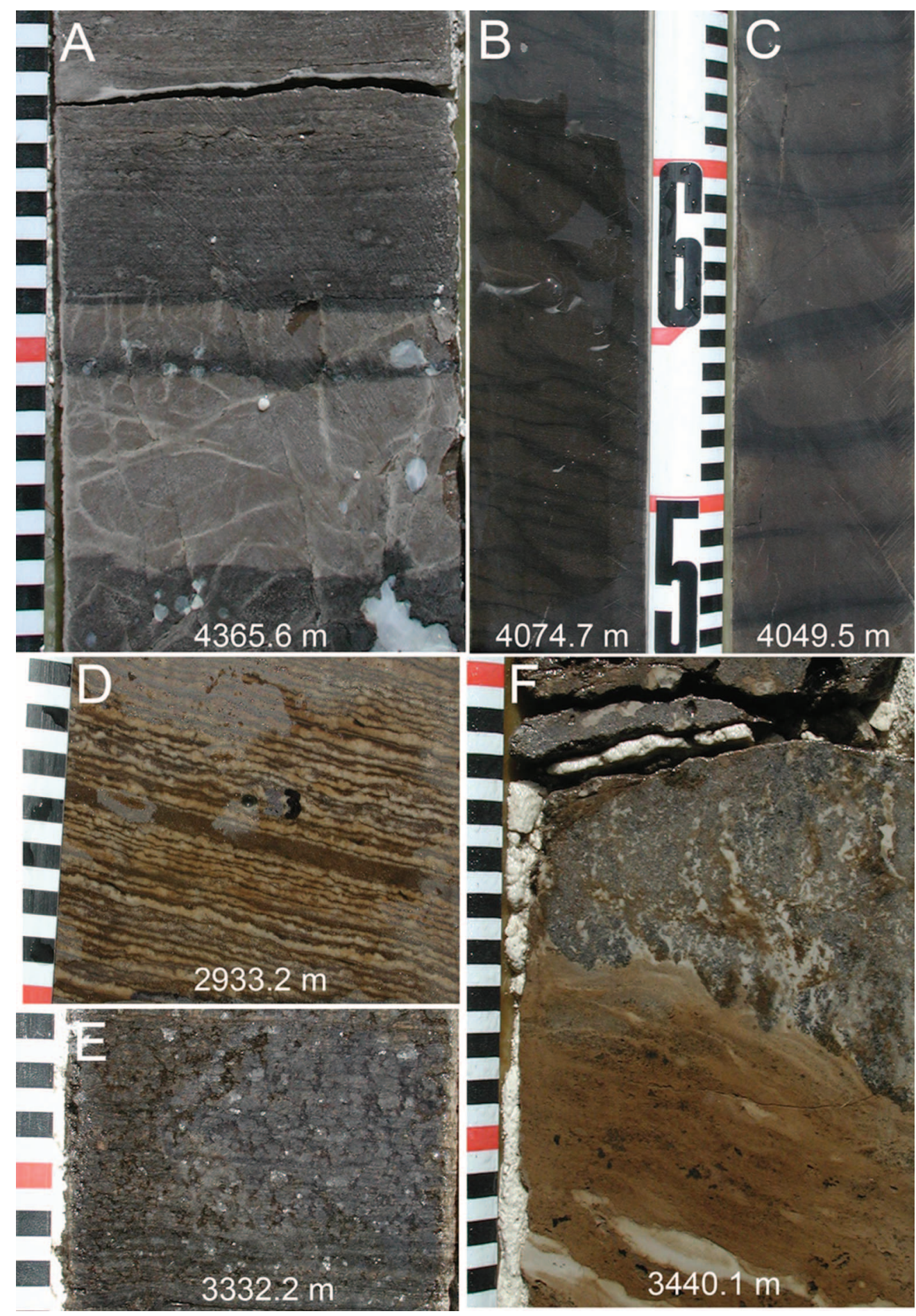

Figure 7. Deep ramp and slope facies. All scale ticks are $1 \mathrm{~cm}(0.4 \mathrm{in}$.). (A) Interbedded finely laminated lime mudstone, and massive lime mudstone. Rabab-1, $4365.6 \mathrm{~m}$ (14,323 ft) depth. (B) Thick-laminated nodular lime mudstone. Ghaniya-1, $4074.7 \mathrm{~m}$ (13,368 ft)

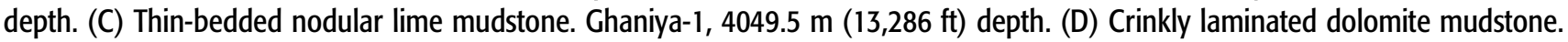
Early dolomitization preserves textural detail, as well as development of intercrystalline porosity. Note that light laminae preferentially have flatter bases, and tops that are more irregular. Dark layers tend to fill and dampen this relief, which may reflect the development of benthic microbial mats. (E) Crinkly laminated lime mudstone. Note coarse, interlocking mosaic of calcite neospar. The lack of dolomitization results in primary fabric destruction, and the neomorphic recrystallization destroys any primary porosity in this facies. Naqawa-1. (F) Reef-derived talus, transported from downslope thrombolite buildup. Block is inverted so that digitate-growth structures point downward. Harweel-1, $3440.1 \mathrm{~m}(11,286 \mathrm{ft})$. 


\section{Interpretation}

Considered collectively, most of these facies fit well the classic model for deeper ramp-to-rimmed-shelf sedimentation (e.g., Read, 1985). The nodular mudstones represent off-shelf transport of muds to form progressively thinner sedimentation increments in progressively more distal locations. The breccias represent steepening of the margin and downslope transport of shelf-derived reef talus, and upper slope mudstones. The nodular mudstones reflect early cementation of alternating laminae, combined with the effects of differential compaction. They are arranged in thickening and upward-thinning successions, which suggest progradation and retrogradation of the platform. These facies are common in downdip locations, and mark backstepping of the platform above flooding surfaces.

The finely laminated mudstones are interpreted to represent the most distal sediments. They were formed by settling from suspension of fine muds, perhaps precipitated during whiting events. Their uniformly evenlamina boundaries indicate purely physical processes involved in development of the facies, in contrast to the crinkly laminites. The intercalated massive mudstone beds are interpreted as remobilized muds, transported off the platform during storms.

The crinkly laminites are interpreted to record the influence of organic accumulation in development of distinctive fabrics. Each light-dark couplet reflects accumulation of carbonate settling from the water column (dark laminae), alternating with accumulation of planktonic and/or benthic organic matter (light laminae). The rough, crinkly, upper boundaries of the light laminae suggest the presence of microbial mats, which might have created upright structures (Grotzinger and Knoll, 1999; Schröder et al., 2005). However, the absence of stromatolites (domes or columns of any kind) implies a different formation mechanism than that of many other microbialites. In this case, the water depths may have been great enough that sediment trapping and binding photoautotrophs were absent or subordinate to other microbial metabolisms, perhaps based on chemoautotrophy. A potential modern analog is provided by the chemoautotrophic mats covering the subphotic seafloor in upwelling zones (Gallardo, 1977; Schulz et al., 1999). These mats cover the seafloor but do not form larger scale growth structures. When covered with thin laminae of sediments and buried, it is possible that crinkly lamination could form. The subsequent diagenesis of this organic matter, in a carbonate-rich environment, could lead to its degradation to form the primary component of the pore system observed in the Ara crinkly laminites (Schröder et al., 2005). In the A4 platform of the Birba cluster, this facies forms a regionally continuous reservoir unit the properties of which likely reflect subtidal microbial processes.

The lamination attributes of the crinkly laminites, their lateral persistence between wells spaced by $\mathrm{km}$ to even $10 \mathrm{~s}$ of $\mathrm{km}$, the absence of any shallow-water structures (cf. mudcracks, intraclasts, and stromatolites), or bedforms (cf. wave or current ripples) all point to deposition in relatively deep water on the order of tens to hundreds of meters. It is less certain what relative influence there was between pelagic and benthic primary production, but colonization by mats in this deeper water setting is suggested.

\section{Subtidal Microbialites Facies Association (SM)}

\section{Description}

The SM facies association includes two gradational facies: pustular laminites and thrombolites. The pustular laminites also may be associated with crinkly laminites.

Pustular laminites show $\mathrm{mm}$ - to $\mathrm{cm}$-scale lamination, again defined by couplets of darker and lighter laminae. Darker laminae have higher organic content and form pustules, larger in scale than crinkles, with small bumpy structures defined by their upper contact with overlying light laminae (Figure 8A). Light laminae are generally dolomitic mudstones that either drape or fill in the topography created by the dark laminae. In contrast, darker laminae may be peloidal, and they contain scattered Cloudina fossils, expressed as small rings in cross section about $1 \mathrm{~mm}(0.04 \mathrm{in}$.) in diameter. Dark laminae also form nucleation points for larger scale growth structures that have relief in excess of $1 \mathrm{~cm}(0.4 \mathrm{in}$.) (Figure 8B). These structures are often onlapped by multiple pustular laminite couplets indicating they had cm-scale relief above the seafloor. These larger scale structures have a massive to 




Figure 8. Subtidal Microbialites. All scale ticks are $1 \mathrm{~cm}(0.4$ in.). (A) Pustular-laminated dolomite. Small circular outlines are cross sections of Cloudina fossils. Dark blebs are bitumen filling primary porosity. Note coarser, more granular, and discontinuous nature of lamination as compared to crinkly laminites. Minassa-1, $3424.1 \mathrm{~m}$ (11,234 ft). (B) Pustular-laminated dolomite with incipient thrombolitic growth structures. Note lack of internal lamination, which distinguishes these from stromatolites. Minassa-1, $3423.3 \mathrm{~m}(11,232 \mathrm{ft})$. (C) Thrombolite. Primary pore space created by $\mathrm{cm}$-scale mesoclots is mostly filled with internal geopetal dolomite mudstone. Rabab$1,4408.2 \mathrm{~m}(14,463 \mathrm{ft})$ depth. (D) Thrombolite. Primary pore space is filled with bitumen followed by later halite cement. Minassa-1, $3397.8 \mathrm{~m}(11,148 \mathrm{ft})$ depth. (E) Thrombolite mound margin defined by vertical to overhanging dip of stromatolitic laminae that encrust the sides of thrombolite. Minassa-1, $3405.0 \mathrm{~m}(11,171 \mathrm{ft})$ depth. 
clotted internal texture and lack any expression of lamination. Thus, they are likely to represent incipient thrombolites. Pustular laminites have good reservoir properties; as with crinkly laminites, dolomitization improves both porosity and permeability.

Thrombolites include a broad range of large-scale microbial growth structures ranging in scale from small mounds with $10 \mathrm{~cm}$ (4 in.) of relief to large reef complexes many tens of meters in relief. They generally have clotted internal textures, created by earlycemented fabric elements (mesoclots; sensu Kennard and James, 1986) that created significant primary porosity. These pores were either filled with geopetal sediments (Figure 8C) or left open to become filled later with marine and burial cements, including pore-occluding halite (Figure 8D). The margins of larger mounds can be detected in core based on the presence of vertical to overhanging stromatolitic crusts (Figure 8E), similar to that documented for thrombolite margins in the age-equivalent Nama Group (Grotzinger et al., 2005).

Thrombolites have the highest primary porosity potential of any facies in the Ara Group, capable of forming loose frameworks with over $50 \%$ primary pore space under normal circumstances. These frameworks can be tighter, reducing primary porosity and permeability, and filled by sediments and cements, as is the case for time-equivalent rocks in Namibia (Grotzinger et al., 2005). However, in the Ara Group, thrombolites remained open until late in the diagenetic sequence, which resulted in their being commonly occluded by halite; indeed, the facies with highest initial porosity-permeability attributes were most susceptible to this effect (Schoenherr et al., 2008). Nevertheless, in platforms where salt plugging is absent or limited, this facies makes excellent reservoirs.

\section{Interpretation}

These facies represent vast tracts of subtidal seafloor that were covered with microbial mats. The crinkly laminites, discussed previously as part of the deeper ramp and slope facies association, very likely record the most distal influence of benthic mats on the seafloor. However, for crinkly laminites the benthic contributions may have been subordinate to the flux of pelagic organics. Further updip, and possibly in the photic zone, the pustular laminites formed welldeveloped benthic mats that helped nucleate small thrombolitic growth structures. In place, perhaps even further updip, these thrombolites were able to attain significant size in which major buildups developed.

The thinly laminated texture, irregular to pustular geometry of laminae, locally truncated laminae, and production of $\mathrm{mm}$ - to $\mathrm{cm}$-scale synoptic relief along the seafloor within the pustular laminites implies the involvement of benthic microbial communities in sedimentation, imparting strength to laminae (e.g., Burne and Moore, 1987; Chafetz and Buczynski, 1992; van Gemerden, 1993; Riding, 2000). The Ara microbial mats likely contained a flourishing and diverse assemblage of terminal Proterozoic cyanobacteria and higher algae as has been reconstructed for other age-equivalent platforms (Grant et al., 1991; Grotzinger and James, 2000; Grotzinger et al., 2005). However, as is true for many inferred microbialites, this influence is difficult to conclusively demonstrate (Grotzinger and Knoll, 1999), as there are no preserved filamentous or coccoid microfossils within the laminites, or indirect features such as filament molds.

The pustular laminites are similar to the crinkly laminites in that rough-topped laminae alternate with smooth-topped laminae of calcisiltite to calcilutite. The rough-topped dark laminae, inferred to have formed in the presence of microbial mats, create rough microrelief along their top surface. Superjacent light laminae, inferred to have been sediment rich, smooth over this microrelief produced by the mats (or matinduced processes), and thus prevent it from being inherited and enhanced in subsequent events of sedimentation during microbial mat growth as shown in Figure $8 \mathrm{~B}$. This process is important in preventing the development of thrombolites or stromatolites; instead, relatively flat yet microbially influenced lamination is maintained (Grotzinger and Knoll, 1999).

The lighter colored fine-grained carbonate muds and silts were likely transported as either the tails of dilute turbidity currents or rain out from sediment suspended by storm and fair weather waves and then transported offshore to the site of deposition. Another explanation for the origin of the laminae is that they are the results of whitings (Shinn et al., 1989), be they biologically (Robbins and Blackwelder, 1992) or abiologically (Ball et al., 1967) produced. Regardless of 
the specific origin of Ara muds, their presence within the microbialite facies indicates deposition from suspension along the ramp. This component of downward settling of suspended sediment coupled with net downdip transport of both suspended and bed loads was a critical factor in the maintenance of longterm ramp morphology. Conditions for the development and propagation of any substantial bed-scale relief along the seafoor would tend to be precluded by the damping influx of finer grained sediments (DiBenedetto and Grotzinger, 2005).

The age-equivalent carbonate platforms of the Nama Group, Namibia, provide excellent analogs for these facies where multiple platforms, superbly exposed in outcrop, show clearly the subtidal origin of these microbial laminites (Adams et al., 2004, 2005; DiBenedetto and Grotzinger, 2005; Grotzinger et al., 2005). The pustular laminite facies of the Ara Group is texturally very similar to the splotchy laminite facies of the Namibian Hoogland ramp (DiBenedetto and Grotzinger, 2005), which can be correlated laterally for at least tens of $\mathrm{km}$ and possibly over $50 \mathrm{~km}$ (>31 mi). It forms down dip of grainstone shoals and thrombolite buildups. The lower energy mid-ramp to outer-ramp setting of the Hoogland splotchy laminites is further backed by a general lack of wave-produced sedimentary structures and fine- to coarse-grained carbonate sediment emplaced by traction currents like those found updip. Stratigraphic data for the Ara Group (see below) indicate that in the SOSB the lateral extent of the pustular laminite (and crinkly laminite) was also very significant.

The growth of large-scale $(>\mathrm{cm})$ thrombolite mounds and larger buildups requires that microbial growth rates outpace the accumulation rate of suspended sediments (Grotzinger and Knoll, 1999; DiBenedetto and Grotzinger, 2005; Grotzinger et al., 2005). In essence, the small bumps seen in the pustular laminites (Figure 8B) need to propagate to a sufficiently large scale beyond which the influx of sediment can no longer fill in the topography they create. Once this stage is reached, thrombolites can grow to a very large size, accommodation constraints permitting. The primary porosity observed in thrombolites is a function of mesoclot geometry and distribution, the flux of marine sediments that invades the pore system, and the growth rate of marine cements that reduces available pore space (Grotzinger et al., 2005).

Thrombolites generally form meter-scale mounds in the Ara Group, although larger scale buildups are also observed. It is important to appreciate that this potential reservoir compartmentalization is compensated by the fact that these mounds and buildups often are interbedded with porous and permeable pustular laminite facies and, further updip, with various grain-rich facies (see below). Thus, they can be treated as lenses with higher primary porosities within potential larger scale flow units.

The association of the pustular laminites and thrombolites with the late Ediacaran metazoan Cloudina is identical to what is observed both in Namibia (Grotzinger and James, 2000; Adams et al., 2004; Grotzinger et al., 2005;) and Canada (Hofmann and Mountjoy, 2001). Though Namacalathus is rare in the Ara Group as compared to these other sites (Amthor et al., 2003), it does occur in association with thrombolites. Cloudina fossils are locally so abundant in the Ara thrombolite facies that they form their own bioclastic reservoir facies (see below).

\section{Clastic-Textured Carbonates}

\section{Description}

These facies are distributed throughout the platform and therefore do not strictly constitute a facies association. Some represent event beds, others represent local concentrations within microbial carbonates, whereas still others form shoal facies. But because the grains that constitute Precambrian platform have unfamiliar or poorly understood origin (Grotzinger, 1989; Grotzinger and James, 2000), it is most instructive to consider them collectively. These clastictextured carbonates include ripple cross-stratified grainstone-packstone, hummocky cross-stratified grainstone-packstone, flat pebble conglomerate, ooid and intraclast grainstone-packstone, and Cloudina grainstone-packstone. These facies are almost invariably dolomitized, and all have moderate to excellent reservoir quality.

The most distal of these facies include ripple cross-stratified and hummocky cross-stratified grainstone-packstone. Dolomitization makes it difficult to evaluate the types of grains, but petrographic 
analysis indicates that peloids may be dominant. The grains range in size from silt to medium sand. Ripple cross-stratified beds feature mostly wave-produced cross-stratification with symmetrical crestlines (Figure 9A), though unidirectional-flow-produced ripples are also observed. Beds are generally $1-4 \mathrm{~cm}$ (0.4-1.6 in.) thick, but can be amalgamated to form thicker composite beds of up to $30 \mathrm{~cm}(1 \mathrm{ft})$. Hummocky cross-stratified beds (Figure 9B) are generally 3-8 cm (1-3 in.) thick and show characteristic low-angle truncation surfaces. These beds generally are not amalgamated.

Intraclast conglomerate beds generally consist of flat pebbles of local derivation that are poorly sorted and form beds that range from 5 to $10 \mathrm{~cm}$ (2 to $4 \mathrm{in}$.) in thickness (Figure 9C). Imbrication is not observed. The intraclasts generally overlie scoured surfaces.

Deposits up to several meters thick are formed of intraclast and ooid grainstone-packstone. Intraclast grainstone-packstone is most abundant and comprises beds up to $50 \mathrm{~cm}$ (20 in.) thick. Bedding is often massive but can be locally trough cross-stratified forming bed sets of 5 to $10 \mathrm{~cm}$ ( 2 to 4 in.). Again, dolomitization precludes definitive grain-type determination, however, grains range in size from fine to medium sand and are likely composed of fine intraclasts or coarser peloids. Some beds can be composed of ooids and coated intraclasts (Figure 9D). These oolites are uncommon and restricted to specific stratigraphic intervals (see below). They can also be trough cross-stratified.

Cloudina grainstone-packstone (Figure 9E) is present only in association with thrombolite reef facies. Specifically, it accumulates along the flanks of mounds within intermound depressions. These bioclasts have shapes of curved cylinders, with circular cross sections when cut normal to the organism growth vector. Other cuts reveal ellipses of varying eccentricity depending on the cut angle, or two parallel straight lines in the case of a longitudinal cut. The bioclasts accumulate to form highly porous networks.

\section{Interpretation}

The various facies all represent sediment transport to form grain-supported textures, often with high initial porosities. Packstones have mud-sized matrix that reduces this control on reservoir quality.

Hummocky cross-stratified grainstone-packstones are classic storm deposits, probably formed by downdip transport of shallower water grains and reworking under conditions of oscillatory shear (Dott and Bourgeois, 1982; Haines, 1988). Ripple cross-stratified beds reflect deposition of grains under less intense oscillatory shear currents probably associated with fair-weather waves (de Raaf et al., 1977). These beds can be amalgamated reflecting the persistence of the currents over longer time scales.

Intraclast conglomerates occur in pustular laminites as well as ooid-intraclast grainstones and are interpreted to represent early lithification of the seafloor to form crusts, followed by reworking of these crusts during storms to form lag deposits (Mount and Kidder, 1993). They are important indicators of environment but do not form deposits thick enough to influence reservoir quality.

Intraclast and ooid grainstone-packstone is the most important reservoir facies in this group. The common dolomitization significantly enhances primary attributes and stratigraphic units formed of this facies have significant lateral continuity (see "Platform Architecture" section). These facies represent shoal and even beach deposits in A1, A2, A3, and A4 platforms, accumulating in the most updip paleogeographic positions. Sediments accumulated with grain-supported textures to form migrating bedforms that created trough cross-stratification. The bedforms may have been formed by either tidal or wave-produced currents. Uncommonly, planar, but low-angle, stratification is suggestive of swash zone processes.

By analogy with identical facies in the Nama Group (Adams et al., 2004; Grotzinger et al., 2005), Cloudina grainstone-packstone formed in response to currents sweeping these organisms off the tops and sides of thrombolite mounds and into the intermound depressions. Current energy need not have been high in the depressions to concentrate these grains, as is true for younger Phanerozoic bioclastic grain-rich accumulations in which prolific growth can produce an equally impressive accumulation, even in quite low energy conditions (Davies and Marshall, 1986). In this context, these are the world's oldest bioclastic reservoir facies. 


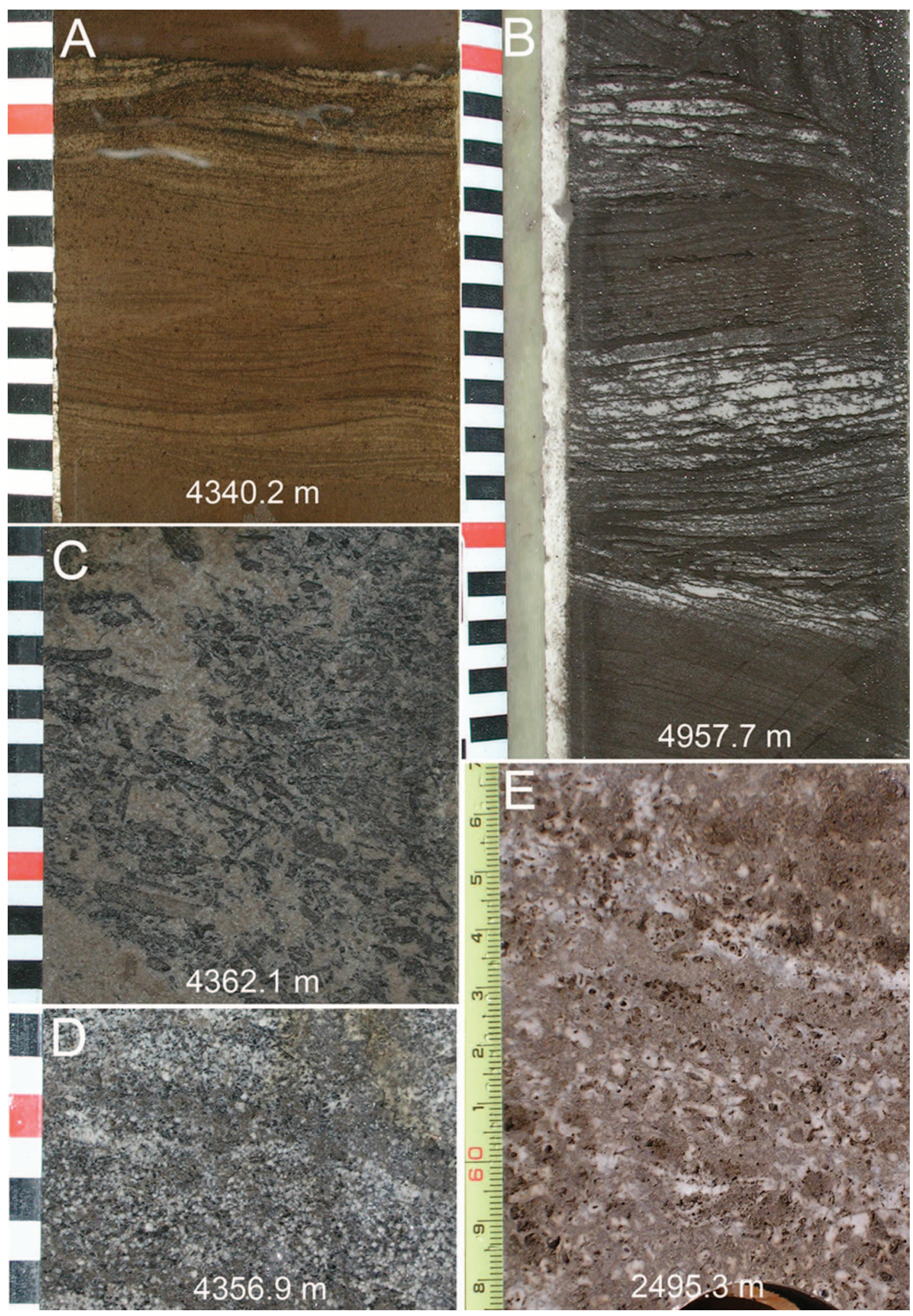

Figure 9. Clastic-textured carbonate facies. All scale ticks are $1 \mathrm{~cm}(0.4 \mathrm{in}$.) unless otherwise noted. (A) Wave-rippled peloidal grain-

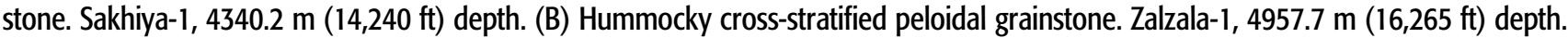
(C) Intraclast grainstone-packstone. Sakhiya-1, $4362.1 \mathrm{~m}$ (14,311 ft) depth. (D) Ooid grainstone. Ghafeer-1, 4356.9 m (14,294 ft) depth. (E) Cloudina grainstone. Fossils have mm-scale cylindrical tube shape; note circular cross sections, and less common elliptical cross sections. Primary pore space contains bitumen. Finest gradations of scale are $1 \mathrm{~mm}(0.04$ in.). Baher-1, $2495.3 \mathrm{~m}$ (8187 ft) depth. 
However, they form lenses rather than sheets and therefore do not have significant lateral extent.

\section{Restricted Peritidal Carbonates Facies Association}

\section{Description}

Peritidal facies representative of restricted environments are uncommon in the Ara Group despite the abundance of evaporites in the basin. They are best developed in discrete stratigraphic intervals of the A3 platform in the Harweel cluster and the A1 platform in the Birba cluster. These facies include brecciated, fenestral mudstones; fenestral-laminated stromatolites; isopachously-laminated stromatolites; crystal-rich mudstones with palisades textures; vadose pisolite; tufted microbial laminites; and brecciated microbial laminites with displacive anhydrite nodules. As used here, "palisades" refers to a bladed crystal texture in which crystals grow perpendicularly to local depositional topography. All of these facies are dolomitized, and those that have fenestral, vuggy, or intergranular porosity have good reservoir potential.

Brecciated, fenestral mudstones form as beds up to $230 \mathrm{~cm}(7.5 \mathrm{ft})$ thick. They are characterized by fenestrae and sheet-like voids that are oriented parallel to bedding, which is extensively disrupted (Figure 10A). Disruption may involve development of small tepee structures. Beds may terminate upward in exposure surfaces.

Fenestral stromatolites occur within these beds and form the only good examples of stromatolites in platforms of definitive A1 and younger ages. In general, stromatolites are very rare in the Ara Group. The fenestral stromatolites are small, limited to a few $\mathrm{cm}$ in width, and with only $1-2 \mathrm{~cm}(0.4-0.8 \mathrm{in}$.) of synoptic relief. Lamination is only moderately well expressed, outlined mostly by the presence of laminoid fenestrae (Figure 10B).

A separate type of stromatolite, equally rare, is characterized by extremely well-expressed isopachous lamination. This isopachous lamination has sub-mm-scale thickness, and it maintains its thickness normal to the surface of the stromatolite, thus having a uniform thickness; as the structure grew upward it also grew outward (Figure 10C). This property is consistent with a group of stromatolites that are known to have grown via precipitation rather than trapping and binding (Grotzinger and Rothman, 1996; Pope et al., 1999; Grotzinger and Knoll, 1999).

Laminated dolomite mudstones may contain lathshaped anhydrite crystals oriented approximately normal to bedding, creating a palisades texture, or otherwise form small bumpy structures. This is expressed as couplets, up to $5 \mathrm{~mm}$ (0.2 in.) thick, formed of darker laminae, which are crystal rich and form growth topography that has mm-scale relief; lighter laminae are pure dolomite muds and tend to fill in the topography created by crystal growth (Figure 10D).

Pisoliths are also rarely developed in the Ara Group, but, where developed, form beds up to $15 \mathrm{~cm}$ (6 in.) thick, with moderately-well expressed reverse grading (Figure 10E). These pisoliths have irregular growth coatings and form fitted fabrics. Occasional mud laminae may drape over the pisolitic deposits. Intergranular porosity can be high.

Microbial laminites are present as part of this facies association, and tufted laminites are most common. As in other Ara microbial laminites, couplets expressed as dark, organic-rich laminae create mm-scale-relief growth topography that is infilled by light, organicpoor laminae, as is the case for other microbial laminites in the Ara. However, these are distinctly different in that the dark laminae form tufts, or peaked-shape topography (Figure 10F). Furthermore, the light laminae that infill topography can be discontinuous due to small fractures that are interpreted as desiccation features; platy intraclasts are also formed by remobilization of these fractured muds. In other cases, deeply penetrating prism cracks (cf. Hardie, 1977) document exposure of these microbial mat facies.

Finally, a microbial laminite facies is present that features irregular discontinuous lamination due to brecciation of laminae at a small scale (Figure 10G). This brecciation is interpreted to result from frequent subaerial exposure on supratidal flats; however, it may also result from displacive growth of sulfate minerals.

\section{Interpretation}

This assemblage of facies includes many classic textures and structures formed in the upper intertidal to supratidal zone of carbonate platforms where environmental restriction occurs due to evaporation of 


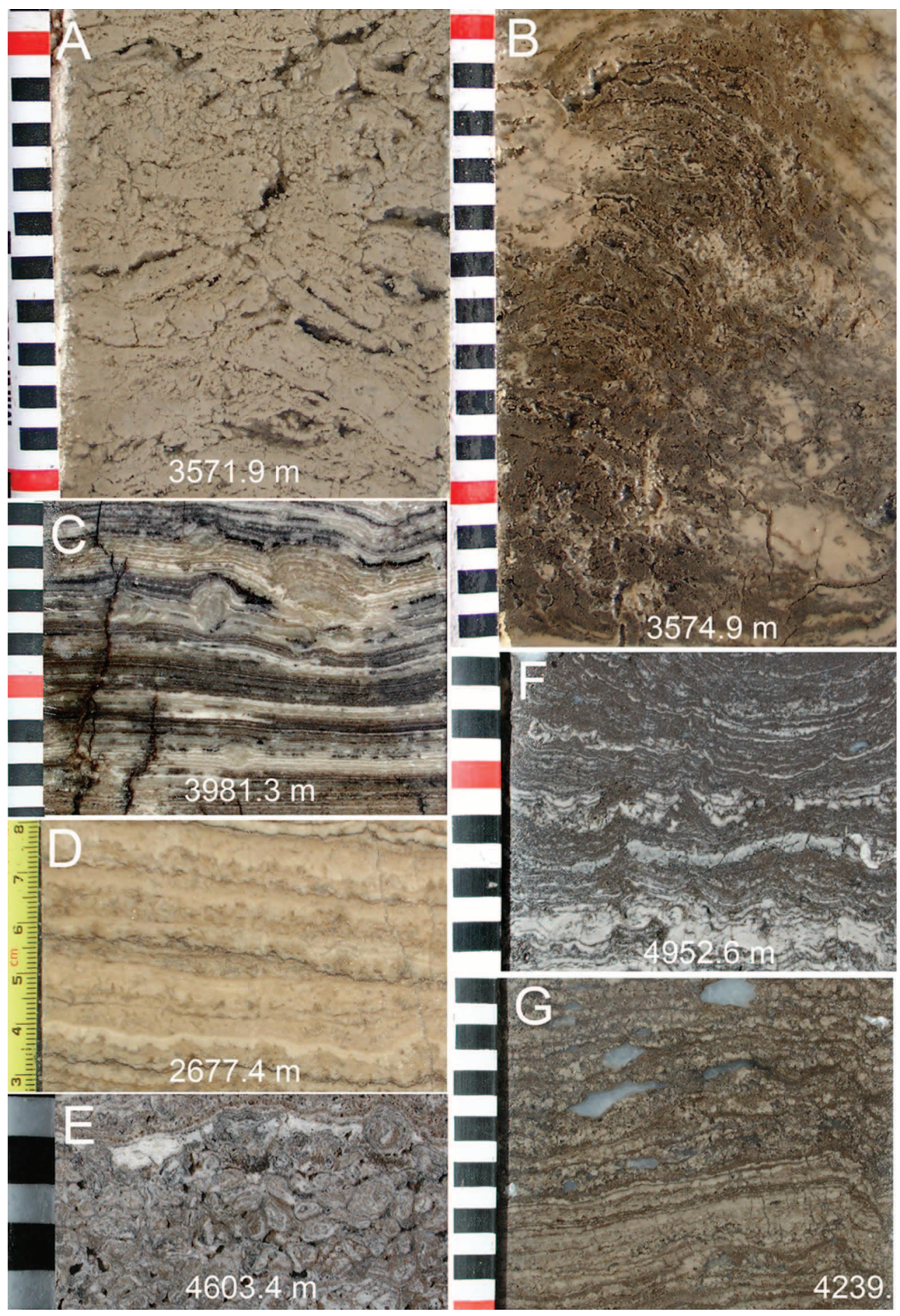

Figure 10. Peritidal Carbonates. All scale ticks are $1 \mathrm{~cm}(0.4$ in.) unless otherwise noted. (A) Brecciated dolomite mudstone. Brecciation due to exposure and desiccation. Reef-1, $3571.9 \mathrm{~m}$ (11,719 ft) depth. (B) Stromatolite defined by irregular, fenestral laminae. This primary porosity is lined with bitumen, then plugged by halite cement. Reef-1, $3574.9 \mathrm{~m}(11,729 \mathrm{ft})$ depth. (C) Isopachous stromatolitic lamination. Note even lamination style and uniform thickness. Minha-1, $3981.3 \mathrm{~m}(13,062 \mathrm{ft})$ depth. (D) Anhydrite laths form palisades texture in laminated dolomite mudstone. Dhahaban East-1, $2677.4 \mathrm{~m}(8784 \mathrm{ft})$ depth. Smallest gradation of scale in $\mathrm{mm}(0.04$


microbial laminite. Dark, organic-rich laminae form tufts that are draped or onlapped by light-toned mudstone laminae. Zalzala-3,

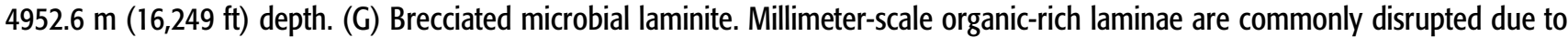
desiccation and precipitation of sulfate evaporites. Ghafeer-6, $4239.4 \mathrm{~m}(13,909 \mathrm{ft})$ depth. 
seawater (Pratt et al., 1992). Brecciated dolomite mudstones, and mud-cracked and brecciated microbial laminites point to sedimentation followed by prolonged subaerial exposure. Vadose pisolite also is interpreted to have formed in occasionally wetted, but vadose, environments; pisoliths would have been reworked during flooding of the exposed surfaces, followed by fresh coating of grains (cf. Esteban, 1976).

The presence of shallow brine pools is suggested by the precipitation of anhydrite, not just as displacive nodules, but as crystal laths that grew upward from the seafloor. This is indicated by the clustering and often upward-divergent nature of the crystal growth habit. It is likely that the isopachouslylaminated stromatolites also formed in shallow brine pools, similar to those in evaporative carbonates of other ages (Pope et al., 1999; Pope and Grotzinger, 2001). These carbonate evaporites formed where seawater was sufficiently concentrated to precipitate mostly abiotic carbonates, but not enough to form sulfates (Pope et al., 1999).

The tufted laminite facies is the most common of the restricted peritidal carbonate facies association, and occupies distinct stratigraphic positions best developed in the A2 and A3 carbonates for the Harweel cluster. It forms in close association with the shoal-forming intraclast and ooid grainstones. Possibly the tufted laminite represents a tidal flat or even shallow lagoon located behind the shoals. The presence of desiccation cracks, including deeply penetrating prism cracks suggests the exposure index was high (cf. Hardie, 1977). Tufts were likely formed by photosynthetic cyanobacteria that self-organized through filament gliding to form tufts, similar to what happens today in Phormidium mats (Walter, 1976; Bosak et al., 2009). When flats were inundated, fine carbonate muds fell out of suspension to drape the mats, as well as onlap and reduce their topographic relief. Subsequently, these muds became desiccated and cracked.

\section{PLATFORM ARCHITECTURE}

In the Southern Domain of the SOSB, the stringers are concentrated in two areas known as the Birba cluster in the north, and the Harweel cluster in the south. Carbonate stringers do occur outside of these clusters and between them, but they are not as abundant, not commonly drilled, and consequently poorly understood.

Birba cluster carbonates flank the Athel trough and, at the A0 to A3 level, have a well-developed microbialite reefal margin, or rim, that passes abruptly into deep-water shales and silicilyte. The A4 ("U" Formation) carbonate platform is developed largely behind (west of) this rim (Schröder et al., 2005) but has basinal equivalents in the Athel trough (Amthor et al., 2005). The A5 carbonates are restricted to small patch reefs located well west of the reefal rim. The A6 carbonates are represented by the Ara Group-capping Dhahaban Formation.

Harweel cluster carbonates at the A1 level form part of a broad but thin carbonate platform, built of a single sequence, which extends throughout the area. The A2 carbonates form a distinct carbonate platform of subregional extent formed of multiple sequences. It has a rimmed morphology for the lower part passing upward into backstepped ramp morphologies. The A3 consists of smaller, more localized platforms, but with greater thickness; these tend to be mostly rimmed shelves. The A4 and A5 carbonates in the Harweel cluster lack reservoir quality and consist mostly of deeper water facies. Possibly, they have shelf equivalents, but these have not yet been drilled. As in the Birba cluster, the A6 is the capping Dhahaban Formation.

Ara platform morphologies range from lowgradient ramps to rimmed shelves, and are as compact as meter-thick (several feet-thick) patch reefs less than $1 \mathrm{~km}(<0.6 \mathrm{mi})$ wide to isolated platforms with reservoir fairways extending several tens of $\mathrm{km}$ or more. Thus, not just one model but a range of models exist, which, fortunately, have many similar facies components and stratigraphically predictable relationships between those facies. One of the major exploration challenges is still to predict the transitions from shallower water reservoir facies to deeper water non-reservoir facies. In the absence of high-resolution seismic data and distinctive well-log signatures, the best approach relies on core-based facies analysis and construction of cross sections. These cross sections and their eustatic, tectonic, and paleoenvironmental implications are presented below. 


\section{Harweel Cluster Platforms}

Harweel cluster platforms, which are known to contain commercial reservoirs, include A1, A2, and A3. The A4, A5, and A6 platforms are all dominated by deeper water mudstones that contain very little primary porosity and largely remain as limestone. However, even where dolomitized these carbonates still have poor porosity and permeability. Figure 3 shows the locations of stringers that constitute the Harweel cluster.

\section{A1 Platform}

The A1 forms a very broad low-gradient ramp composed of a single sequence (Figure 11). Though only a few wells penetrate this platform, the facies and seismic data suggest it has broad extent, at least $100 \mathrm{~km}^{2}$ $\left(38.6 \mathrm{mi}^{2}\right)$. The stringer is thickest at Minassa-1 (75 $\mathrm{m}[246 \mathrm{ft}]$ ), and thins toward the Dhahaban South area $(50 \mathrm{~m}[164 \mathrm{ft}])$. This change occurs over a distance of almost $30 \mathrm{~km}$ (18.6 mi). Available data indicate that it has been completely dolomitized.

In the Minassa-1 well, the A1 platform consists of a single depositional sequence that can be correlated to the Dhahaban South wells using a simple model. This single sequence involves flooding of the underlying halite and deposition of anhydrite-dolomite rhythmite at the CET, deepening to depths of maximum flooding where a likely continuous blanket of crinkly laminite facies was deposited. Early highstand deposition involved shallowing into pustular laminite facies, and then into thrombolite facies, followed by late highstand progradation of intraclast grainstonepackstone facies (Figure 11). The lateral continuity of this sequence is suggested by matching facies near the top of the A1 platform in the Dhahaban South area.

The cross section shown in Figure 11 reflects this assumption, and the CET at the top of the platform is used as the datum. Selection of this datum has the effect of revealing differences in subsidence rate, and so the likely downdip direction will be in the direction of increasing thickness. A direct analog for this is provided by the Omkyk Member, Kuibis Platform, in Namibia (see Adams et al., 2005; Grotzinger et al., 2005). The Kuibis thrombolite unit expands laterally during early highstand time, but then is terminated as grainstone sediment flux increases during late highstand time. This model accommodates all of the grainstones as a seawardprograding shoal complex.

In the Minassa-1 well, the crinkly laminite and pustular laminite facies show average porosities of $>10 \%$ and define the main reservoir. The thrombolite and grainstone-packstone facies had originally higher porosities, but pores were plugged by diagenetic halite; in the Minassa-1 well, these facies are non-reservoir because of this plugging. However, in the absence of salt plugging it is important to note that with the exception of the CET facies the entire overlying platform is comprised of facies with very high reservoir potential.

\section{A2 Platform}

The A2 carbonates in the Harweel cluster form a broad isolated platform of several tens of $\mathrm{km}$ in width, and with at least several tens of meters of depositional relief. The A2 platform has a complex stratigraphy that consists of five sequences that preserve evidence of rim building and backstepping. The platform has been extensively drilled and is known to be approximately $50 \mathrm{~km}$ (31 mi) long and $30 \mathrm{~km}$ (18.6 mi) wide; however, these are maximum estimates given that halokinesis has broken the platform apart and distributed the fragments (Figure 3). Assuming some reassembly of the mobilized blocks yields estimates for the reservoir-bearing parts of the platform of $\sim 600 \mathrm{~km}^{2}\left(\sim 232 \mathrm{mi}^{2}\right)$. The platform is thickest at Zalzala and Sakhiya (105 m [344 ft]) and thins outward toward its limits near Rabab-1 in the northeast (80 m [262 ft]), Qashoob-1 in the southwest (85 m [279 ft]), Reef-1 in the north (62 m [203 ft]), and Shujairat-1 in the south (74 m [243 ft]). A variety of shallow-water facies are time equivalent to downslope and basinal nodular mudstones (Figure 7B, 7C).

The five sequences that comprise the A2 platform define a lower platform (sequences 1 and 2), and an upper backstepped platform (sequences 2-5). The cross sections shown in Figures 12 and 13 demonstrate that a lower platform margin exists in the Rabab area; at other locations data are insufficient to delineate additional platform margins. The backstepping of the upper platform is best observed in the northeast-southwest cross section (Figure 12).

The S1 and S2 sequences stack to form a net upward-shallowing package in the lower half of the 


\section{SW}

Dhahaban South-1

$\nabla \nabla$ Dhahaban South-3

$0 \mathrm{~km} 3$
Minassa-1 Reef-1
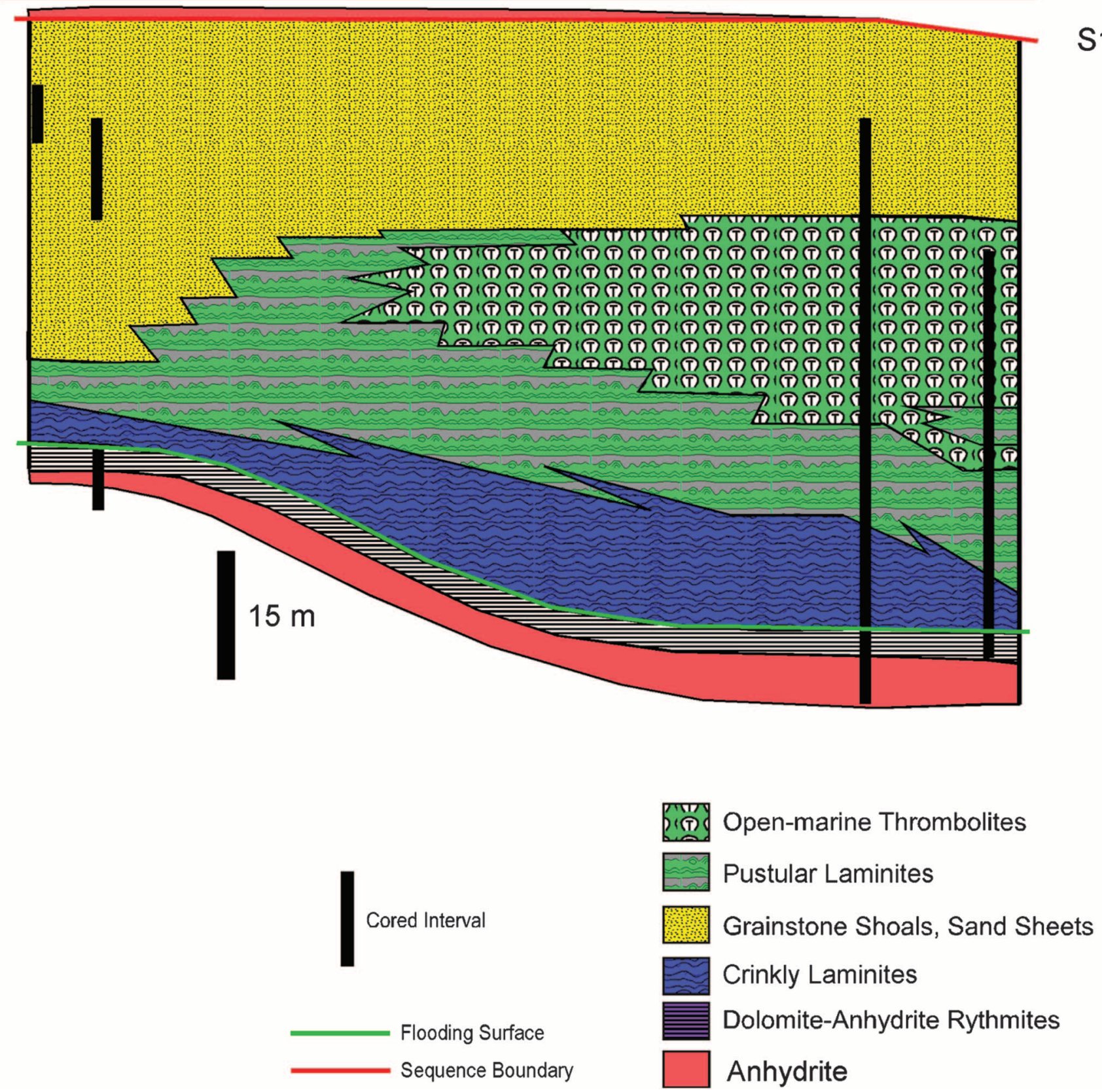

Figure 11. Al cross section, southwest-northeast. See text for discussion and Figure 3 for location.

stringer (Figure 12). The boundary at the top of Sequence 2 is used as the correlation datum for the cross section. This surface represents a regional subaerial exposure surface with development of laterally extensive, often coarse grainstones just above it as a backstepping transgressive systems tract (TST) facies. In addition, exposure resulted in development of vuggy porosity and zones of brecciation in the S2 and even S1 


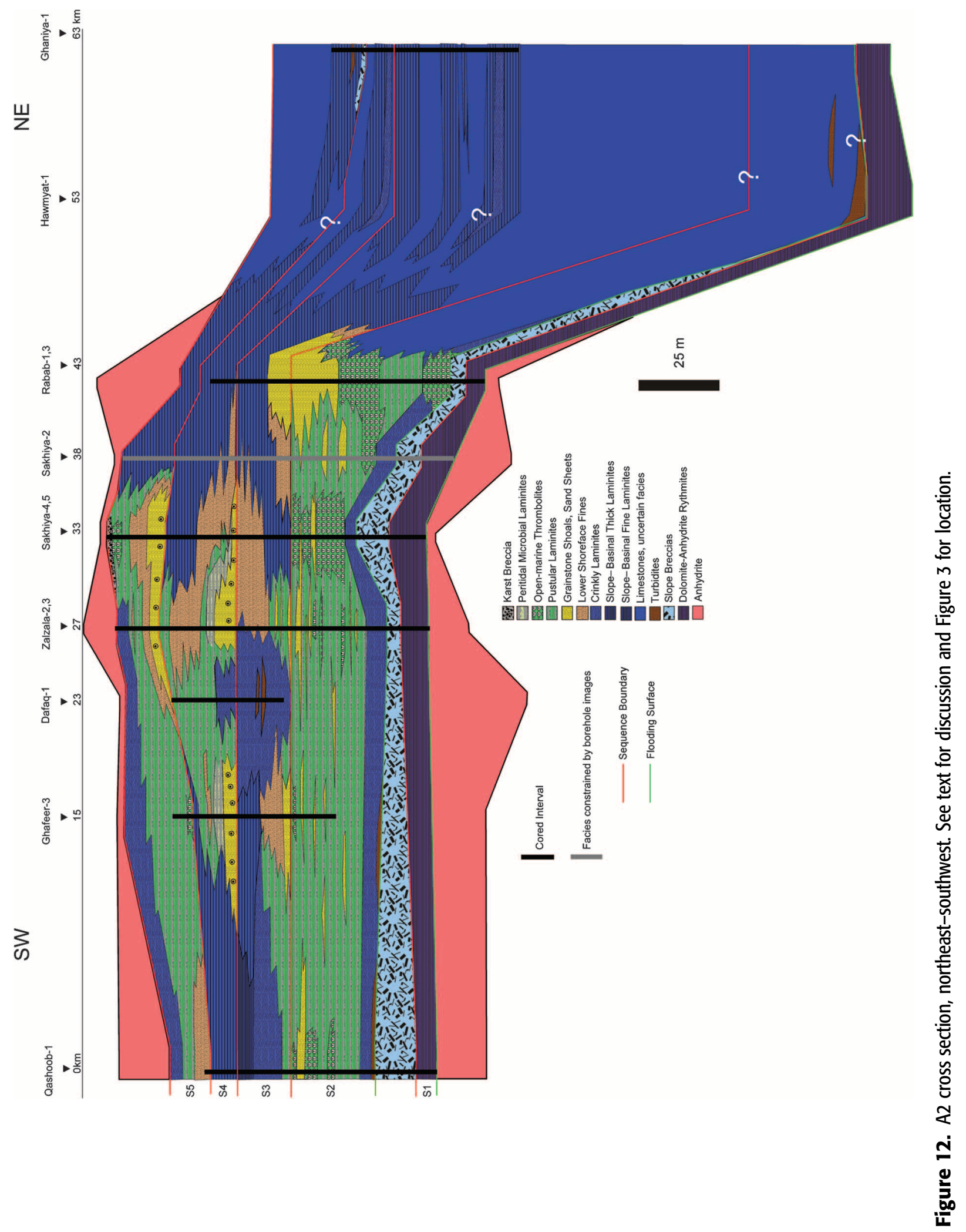




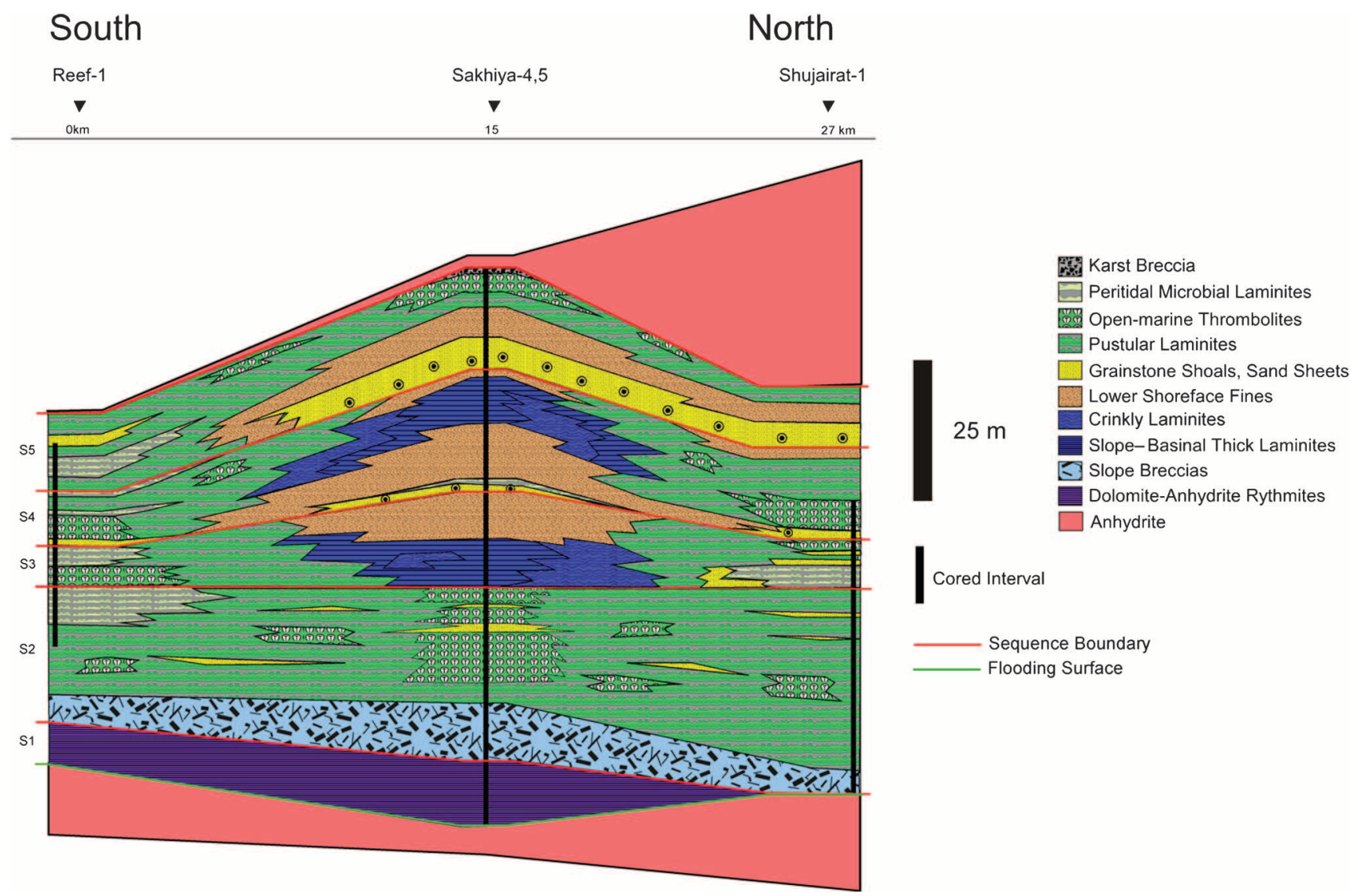

Figure 13. A2 cross section, north-south. See text for discussion and Figure 3 for location.

sequences. Brecciation is most intense in Fayrouz-1 and Rabab-1.

Sequence 1 -Sequence 1 begins with development of a TST, in which deepening and freshening of seawater occurred simultaneously. Initial carbonate deposits were anhydrite-dolomite rhythmites. This was followed by the emplacement of stratiform breccia facies, some of which show the characteristics of sediment gravity flows. The breccia-bearing interval is of uniform thickness; the Sakhiya-5 well penetrates their full thickness and demonstrates interfingering with crinkly laminites, for example between Zalzala-4 and Zalzala-2 in Figure 14.

The occurrence of a sequence boundary at the base of the breccia-bearing interval is subtle, and perhaps Sequence 1 and Sequence 2 alternatively may be viewed as a set of genetically related strata (i.e., a single sequence) that reflect upward shallowing to the S2 sequence boundary. The abrupt emplacement of the breccias suggests a decrease in accommodation space, perhaps due to exposure and collapse.
However, the breccias also suggest deposition from mass flows and even as turbidites. Note their interfingering with crinkly laminite facies at Zalzala-4 (Figure 14).

The breccias of Sequence 1 deserve some further discussion in terms of their composition and possible provenance. These breccias consist of angular to rounded clasts of resedimented rhythmites, massive carbonate mudstones, and anhydrite. Identical breccias also occur at the base of the A3 platform in the Ghafeer area (see next section), and suggest a common, more generic mechanism. The stratigraphic evidence for interfingering with crinkly laminites (Figure 14), and the sedimentological evidence for emplacement as sediment gravity flows (Figure 6D, E) suggest these breccias were likely a response to slope steepening rather than just evaporite collapse. The absence of reef-derived or other shallow-water lithologies in the clast population implies that slope steepening may have been achieved through halokinetic processes. One possibility is early deformation 




Figure 14. A2 cross section, Zalzala field, southwest-northeast. See text for discussion.

of the salt due to loading, with the subsequent effect that uplifted areas become unstable, triggering detachment and sliding of previously deposited deep-water sediments and early transgressive evaporites. Further uplift may have resulted in the development of shoals over the highs, to become updip localities, whereas zones of differential subsidence localize the downdip platform positions. Therefore, it is conceivable that the northeast-southwest depositional dip that is expressed in the stratigraphy of the Zalzala-Sakhiya area results from early differential movement of the salt as it became buried. Early halokinesis could have been triggered or amplified by coseismic shaking during growth faulting in the Ara basin.

Sequence 2 -Sequence 2 is the thickest sequence and consists predominantly of pustular microbial laminite, with embedded, mostly isolated, tabular thrombolite reefs (Figures 12, 13). The thickest of these occurs at Fayrouz-1, where a single buildup of $18 \mathrm{~m}(59 \mathrm{ft})$ occurs. A large buildup also can be seen in Zalzala-4 (Figure 14).
The boundary at the top of Sequence 2 is used as the correlation datum for the cross section. This surface was likely subaerially exposed with development of dissolution textures along it (well preserved in Ghafeer-2, Ghafeer-3, and Rabab-1 cores). It also is possible that breccias beneath it, such as those at Rabab-1, are the result of karst. The thrombolites in Sequence 2 typically preserve a high proportion of limestone, and are brecciated, possibly due to exposure along the S2 boundary.

The differential thickness created by the buildups helped to accentuate local depositional dips within the A2 platform. This differential depositional topography was compensated and infilled by onlap of grainstones in the overlying A3 sequence.

Significantly, the dominance of microbialites in the $\mathrm{S} 2$ sequence helped establish a steep margin along at least the north-northeast margin of the A2 platform (Figure 12), close to the Rabab wells. It is not known whether this was a rimmed shelf, or a distally steepened ramp (sensu Read, 1985) due to the absence of tightly spaced wells in the critical transition zone. 
However, A2 carbonates encountered northeastward from Rabab, in the Ghaniya and Hawmyat wells, indicate thick sections of non-reservoir deep-water mudstones (Figure 12). Backstepping of this platform margin occurred in association with flooding above the $\mathrm{S} 2$ sequence boundary.

Sequence 3-The TST of Sequence 3 represents a regionally discontinuous but locally substantial (at field scale) grainstone deposit. Core data indicate that this deposit of coarse intraclast-peloid grain-

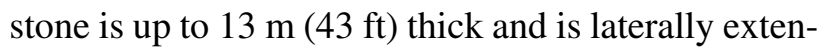
sive at the scale of individual fields (Figure 14). However, this reservoir-prone facies is ultimately limited to the east beyond the Rabab wells where grainstones pass laterally into deeper water laminated slope mudstones (Figure 12). This same lateral transition may occur between the Ghafeer and Qashoob wells to the west.

A flooding surface caps these grainstone deposits, which pass upward into finer, outer shoreface grainstones at Ghafeer and Zalzala-1. In contrast, Sakhiya-2 and Rabab-1 grainstones pass upward into deep-water mudstones, providing clear evidence of the southwest-northeast facies gradient. Sequence 3 is truncated so that it consists only of a TST.

Sequence 4-The upward-deepening trend expressed by the TST of Sequence 3 is abruptly truncated through the introduction of very coarse, commonly oolitic, grainstones emplaced directly above deeper water fine grainstones and mudstones (Figures 12-14). The base of these grainstones represents an abrupt downward shift in facies that can be traced to the northeast where fine grainstones are emplaced on deepest water mudstones at Rabab-1. Progradation locally occurred within these lowstand grainstones, which pass upward into peritidal tufted laminites from Ghafeer to Zalzala-1. A flooding surface occurs at the top of these tufted laminites, which are overlain by a second, regionally continuous interval of outer shoreface fine grainstones. These facies may be restricted to the Zalzala-1 area, whereas to the northeast deep-water mudstones occur at Sakhiya-2 and Rabab-1; to the southeast deep-water mudstones occur in the Ghafeer area (Figure 12). The highstand system tract of Sequence 4 consists of pustular laminites that pass laterally into grainstones; these grainstones show a backstepping relation at Zalzala. These grainstones may form the TST of a fifth sequence, and represent the top of the stringer. They pass laterally to the northeast into deep-water mudstones at Sakhiya-2 and southeast into the deep-water mudstones at Ghafeer-3.

Sequence 5-Sequence 5 records mostly TST deposition within the carbonates of the A2 (Figures 12-14). Facies deepen upward above the S4 sequence boundary, so that shallow subtidal, coarse grainstones just above the boundary pass laterally and vertically into fine grainstones. These facies are overlain by pustular laminite deposits that locally contain small thrombolite mounds, for example at Sakhiya (Figure 13).

Significantly, the uppermost few meters in the Sakhiya-4 core reveal a distinctive breccia that is rarely recorded in the A2 wells, because of a lack of core sampling of the carbonate-evaporite transition. This breccia may represent either a karst or evaporite collapse event, but in either case, it signals an abrupt transition from an upward-deepening (TST) phase to a lowstand phase, without an intervening highstand.

\section{A3 Platform}

The A3 carbonates in the Harweel cluster form a smaller but thicker isolated platform, as compared to the A2 platform. They also have a simpler stratigraphy formed of just two sequences, which preserve evidence of rim building followed by drowning. The platform is known to be approximately $30 \mathrm{~km}$ (19 mi) long and $15 \mathrm{~km}$ (9 mi) wide (Figures 15, 16). As was the case for the A2 platform, these are maximum estimates given that halokinesis has broken the platform apart and distributed the fragments (Figure 3). Relative to the A2C stringer, the A3C stringer displays highly variable thickness over most of the study area. Ghafeer-1 is just over $100 \mathrm{~m}$ (328 ft) in thickness, whereas Sarmad-1 is over $160 \mathrm{~m}(525 \mathrm{ft})$ in thickness. Because the evaporitecarbonate contacts that bound platforms are very likely to be time lines, this implies that a significantly greater amount of subsidence occurred in the Sakhiya area as compared to the Ghafeer area (Figure 15). The stringer thins systematically from Sarmad-Harweel 


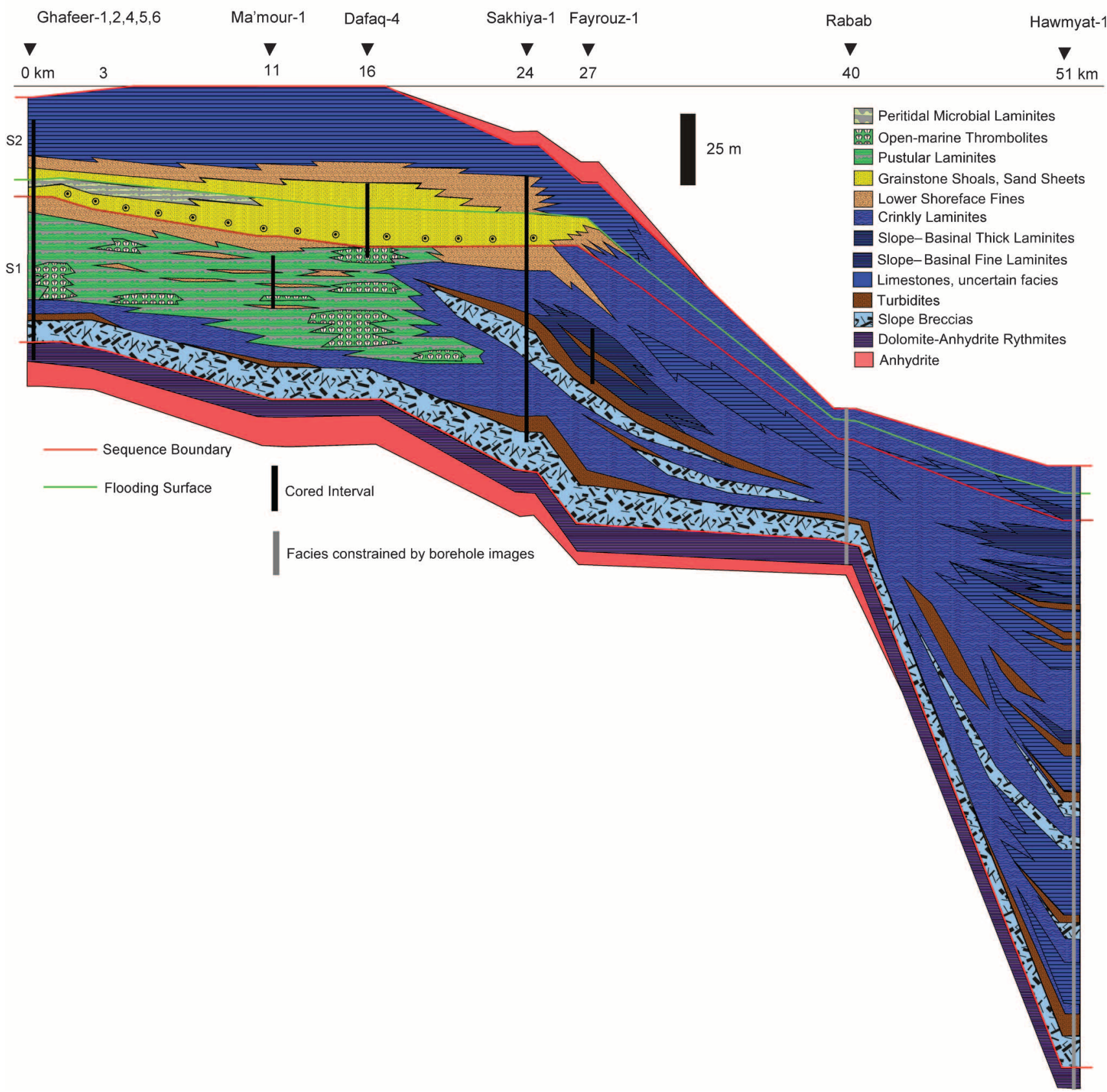

Figure 15. A3 cross section southwest-northeast. See text for discussion and Figure 3 for location.

to Sarmad-2 (Figure 16). The platform is thickest at Harweel-Sarmad (200 m [656 ft]), near its center, and thins outward to 100 to $150 \mathrm{~m}$ (328 to $492 \mathrm{ft}$ ) toward its limits near Ghafeer-1 in the southwest and Sakhiya-1 in the north.

The two sequences that comprise the A3 platform highlight the shallow-water reservoir facies that straddles their intervening sequence boundary, shown in
Figures 15-17. The CET at the top of Sequence 2 is used as the correlation datum for the cross sections. The S1 sequence forms a net upward-shallowing package in the lower half of the stringer, which is observed in all locations where shallow-water platform facies are observed. Above the sequence boundary, the wells which define the southwest-northeast cross-section (Figure 15) show a upward-deepening trend that results 


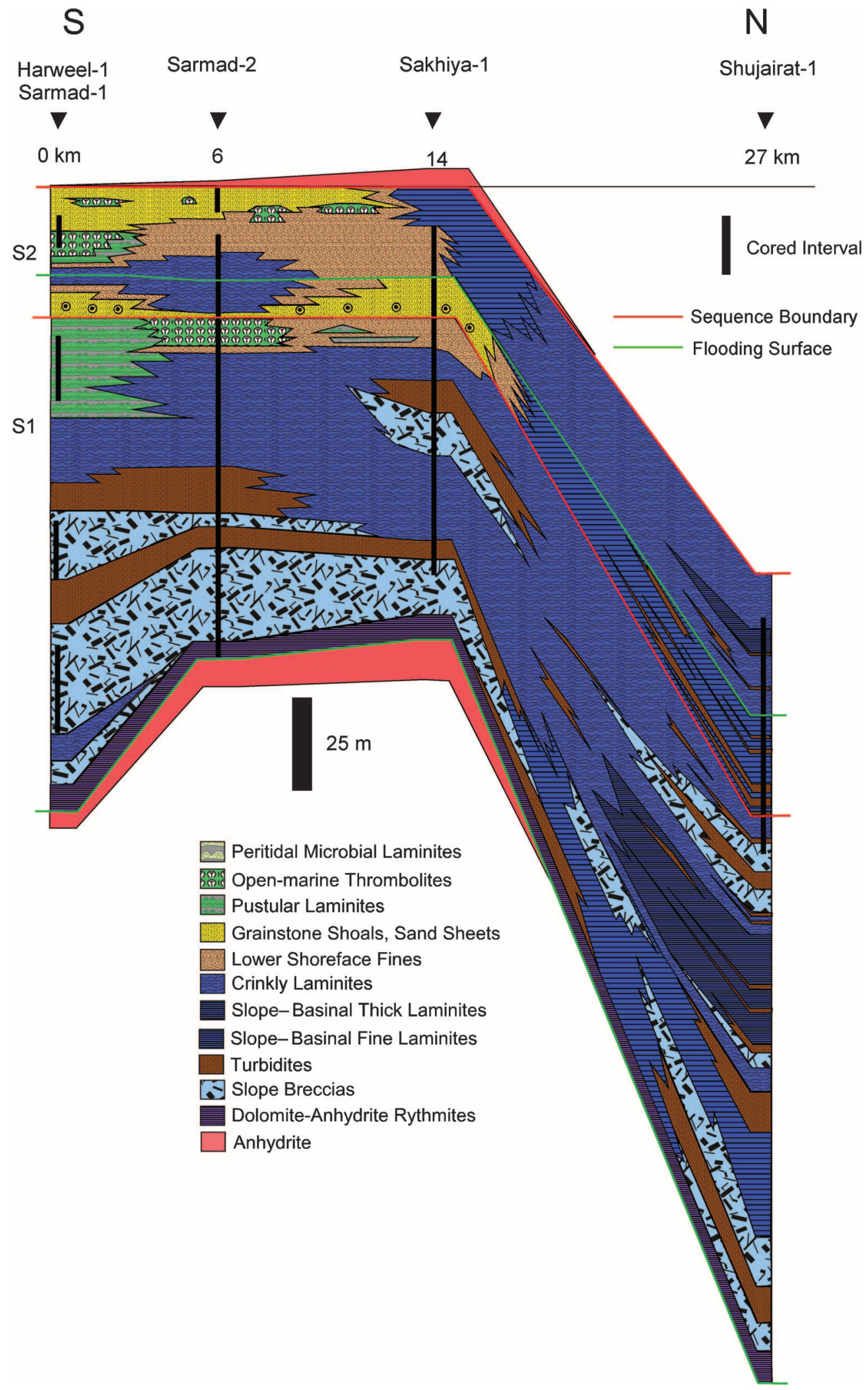

Figure 16. A3 cross section, north-south. See text for discussion and Figure 3 for location. 




Figure 17. $A 3$ cross section, Ghafeer field, southwest-northeast. See text for discussion.

in drowning at this location. This is also seen at a more local scale within the Ghafeer field (Figure 17). In contrast, the wells which constrain the north-south cross section (Figure 16) provide evidence for maximum flooding followed by development of shallow-water reservoir facies at the top of the stringer.

Sequence $1-$ Similar to the A1 and A2 platforms, Sequence 1 in the A3 platform begins with development of a TST, in which deepening and freshening of seawater occurred simultaneously. Initial carbonate deposits were anhydrite-dolomite rhythmites. This was followed by the emplacement of stratiform breccia facies, likely above a sequence boundary. As in the A2 carbonates, some of these A3 breccias show the characteristics of sediment gravity flows (Figure 6D, E). These breccias are also locally overlain by graded, turbiditic beds (Figure 17) The breccia-bearing interval is of fairly uniform thickness; the Sarmad-2, Ghafeer-5 and Ghafeer- 6 wells penetrate their full thickness to display features similar to basal breccias in the A2 platform (Figures 16, 17).

Initial aggradation and progradation resulted in strong platform-to-basin differentiation (Figures 15, 16). Deposition in updip, more southerly locations featured shallow-water thrombolites and pustular laminites that pass downdip into deeper water crinkly laminites, and further downdip into slope deposits consisting of mudstones, turbidites, and reef-block olistostromes (Figure 7F). Thrombolites form discrete buildups with limited lateral extent as shown in the Ghafeer field (Figure 17). With time, accommodation space was infilled by prograding outer shoreface deposits consisting of wave-influenced peloidal grainstone-packstone. A distinct surface, possibly subaerially exposed, marks the top of Sequence 1 (Figures 15-17).

Sequence 2-The sequence boundary at the top of Sequence 1 is abruptly overlain by distinctly coarser, often oolitic intraclast grainstone 


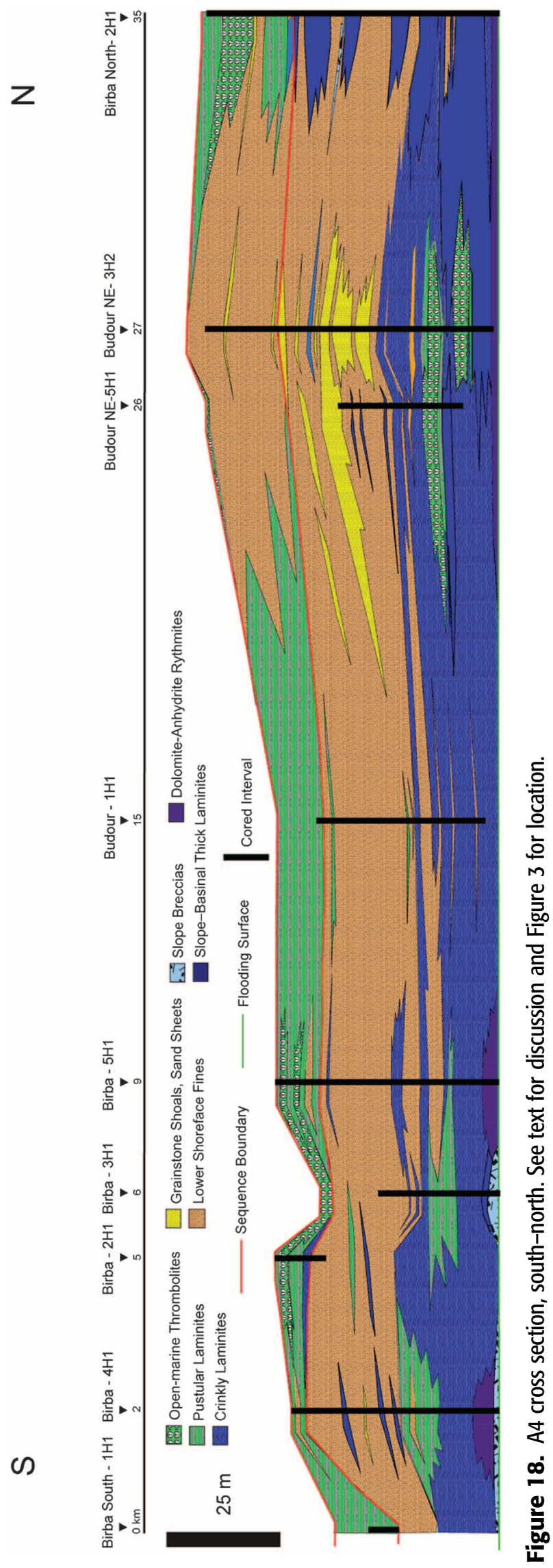

(Figure 9D). These grainstones represent lowstand deposition and extend abruptly downdip into the basin (Figures 15, 16). The lowstand grainstones are capped by a flooding surface that extends across the shelf, capping a thin veneer of transgressive grainstone observed in cores at Sarmad-2 and Ghafeer-1. Thrombolites locally form small patchy buildups of limited lateral extent (Figure 17). This flooding event is significant, with deep-water crinkly laminite mudstones extending across most of the shelf. It is notable, however, that at Harweel-Sarmad and Sakhiya that higher sediment flux prevented flooding of the platform resulting in deposition of wave-influenced outer shoreface fine grainstones (Figure 16). Out-of-the-plane effects are further indicated at the top of Sequence 2 where shallow-water thrombolites and grainstones cap the section at Harweel-Sarmad and Sarmad-2 (Figure 16). This pattern is suggestive of progradation from an easterly or westerly direction. As in the case of the A2C stringer, this provides some evidence for the localization of the reservoir fairway in this paleogeographic position, at least for Sequence 2; in the case of Sequence 1, the fairway would have been optimized at the Ghafeer area and further south.

\section{Birba Cluster Platforms}

\section{$\mathrm{A} 1-\mathrm{A} 3$, and $\mathrm{A} 5$ Platforms}

These platforms will not be discussed in detail due to absence of integrated data, particularly cores, to document these platforms as comprehensively as their equivalents in the Harweel cluster. Furthermore, the A1 platform in the Birba cluster is currently being re-evaluated with much recent drilling activity (Bergmann et al., 2012). In summary, at the eastern limit of the cluster the A1 carbonates may merge with A0 and older carbonates. It is possible that the A2 and A3 carbonates also become stacked as a single, well-developed rimmed carbonate platform.

The A2 platform is considerably thinner than in the Harweel cluster, and consists of interbedded dolomites and anhydrite-rich intervals. Only one core is available through this interval that suggests a restricted depositional environment featuring small stromatolitic domes with isopachous and tufa-like 
Figure 19. Reservoir units of the

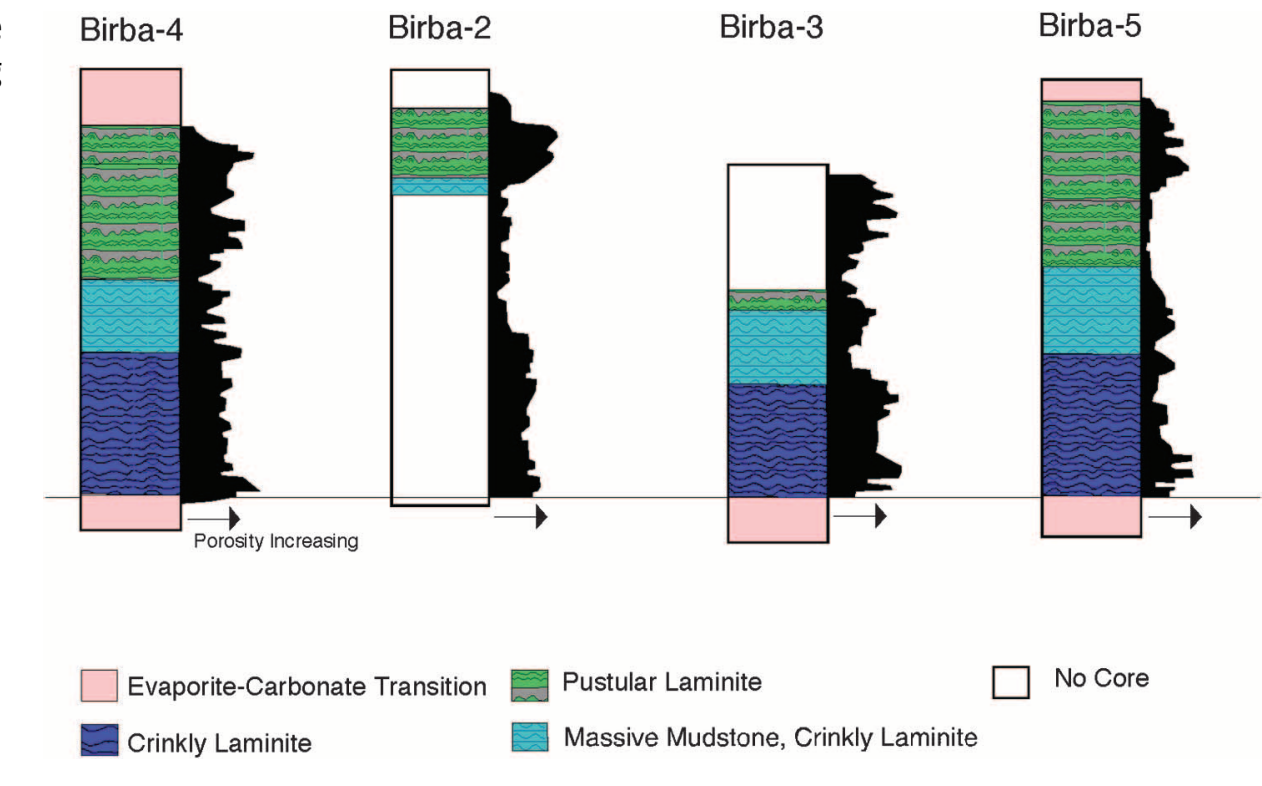

A4 platform, Birba cluster, showing facies and reservoir units of a subset of representative wells used in the study. Facies interpretation is based on core descriptions as shown in Figure 18. Porosity was derived from logs. Reservoir units were calibrated with lithofacies.

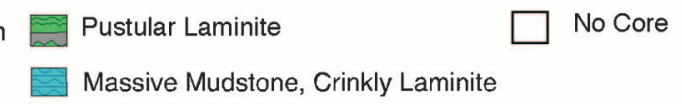

lamination, as well as shale, minor intraclast grainstone-packstone, desiccation-cracked mudstones, and abundant gypsum casts. It is on the order of 50 $\mathrm{m}$ (164 ft) thick.

The A3 platform is very similar to what is observed in the Harweel cluster, both in thickness and in facies. Porosity can be well developed, and production occurs from a handful of wells (Al-Siyabi, 2005). The A3 platform is on the order of 100 to $130 \mathrm{~m}$ (328 to $426 \mathrm{ft}$ ) thick. Core data provide evidence for a lower unit of deeper water, finely laminated mudstones and crinkly laminites; debris flow breccias and turbidites occur near the base, above the carbonate-evaporite transition zone. An upper unit contains grainstones and well-developed thrombolite buildups.

The A5C consists of dolomites with locally welldeveloped porosity. A single core shows the presence of isolated thrombolite pinnacle reefs, up to $60 \mathrm{~m}$ (197 ft) thick.

\section{A4 Platform}

Historically, the A4 platform is the most important reservoir-bearing platform in the Birba cluster, and it has consistently produced since it was discovered in 1976 with the completion of the Nasir-1 well (Al-Siyabi, 2005). Exploration for intrasalt carbonates began in 1977 with the drilling of Birba-1 and continues to this day. The A4C platform has been previously documented by Schröder et al. (2005), whose descriptions we largely follow here. One important difference is that additional drilling over the past $6 \mathrm{yr}$ has shown the presence of two sequences rather than the single sequence proposed by Schröder et al. (2005, their figures 5, 13). Evidence for the second sequence is best expressed in the northernmost wells (Budour northeast) where a second phase of progradation can be observed (Figure 18).

The A4 platform has a simple stratigraphic architecture and consists of two sequences that were deposited across most of the Birba cluster area. The platform thickens from $35 \mathrm{~m}(115 \mathrm{ft})$ in the south to $65 \mathrm{~m}(213 \mathrm{ft})$ in the north (Figure 18). Most major facies are laterally continuous over the $35 \mathrm{~km}$ (22 mi) shown in the cross section. However, thrombolite buildups are localized at the top of the platform in the Birba-2-3-5 area, and near the base of the platform in the Budour northeast area. In addition, a significant thickness of fine, outer shoreface grainstone-packstone is localized in the Budour northeast area.

Carbonate deposition began during flooding of evaporites that were dissolved and reworked, forming a transgressive lag. A volcanic ash was deposited along this transgressive surface and yields a $\mathrm{U}-\mathrm{Pb}$ zircon age of $541.00 \pm 10.13 \mathrm{Ma}$, which closely approximates the Precambrian-Cambrian boundary (Bowring et al., 2007). Initial transgression resulted in deposition of anhydrite-dolomite rhythmites, followed by deposition of a laterally extensive sheet of deeper water crinkly laminites (Figure 18). The crinkly laminite facies (Figure 7D) forms much of 
the A4 reservoir. Overlying highstand carbonates are composed of crinkly laminites that become progressively interbedded with massive mudstones, including muddy debris flows that reduce reservoir quality. Locally, these facies are overlain by fine, outer-shoreface grainstones, but mostly they are succeeded by pustular laminites with small, laterally restricted thrombolites buildups and rare peritidal carbonates including fenestral laminites and stromatolites, brecciated microbial laminites, and brecciated dolomite mudstone. Toward the top of the sequence facies become restricted, signaling the transition into higher salinities associated with the next evaporite (Schröder et al., 2005). It is significant to note that as in the case of the Harweel platforms, the A4 platform in the Birba area is associated with deposition of evaporites not only in downdip positions, but also on top of the platform, indicating strong subsidence during evaporite deposition (Amthor et al., 2002; Schröder et al., 2005).

The crinkly laminites in the lower third of the platform are one of two major reservoir units in the A4 (Figure 19). This is unusual as compared to the other Ara platforms, where grainstones, pustular laminites, and thrombolites form the best reservoir facies. In the A4 platform, these facies form the upper reservoir unit (Figure 19). The A1 platform in the Harweel cluster also contains abundant crinkly laminites that have significant reservoir potential. However, the Harweel A1 crinkly laminites are plugged by halite, dramatically reducing porosity and permeability. Harweel A3 crinkly laminites occur at maximum flooding in Sequence 1 and Sequence 2, but dolomitization likely occurred after compaction and collapse of the early-diagenetic fenestral pore system. Therefore, it is worth summarizing the key points that led to preservation of porosity and permeability in the A4C crinkly laminites. This reservoir unit (essentially the lower third of the platform) has porosities that range from 0.4 to $23.0 \%$ and permeabilities that span 0.01-313 mD. Schröder et al. (2005) interpret the favorable reservoir quality of this unit to be the result of both primary and diagenetic factors: the absence of fine grained mudstones in the lower part of the crinkly laminated unit contributes to the development of vertical as well as horizontal connectivity of pore networks; early dolomitization before significant compaction to preserve microbially generated fenestrae and to develop pervasive intercrystalline porosity. Later, coarse dolomitization and calcite cementation reduced porosity. It is clear that the crinkly laminite facies is a fragile reservoir type and several factors need to coincide for it to be economic.

The mudstones and peloidal packstones (outer shoreface fines) of the middle part of the platform have poor reservoir quality due to their initial fine grain size and despite pervasive dolomitization. However, good reservoir quality returns in the upper part of the platform associated with the peritidal facies. Reservoir quality is highest in the grainstones that are locally developed as lenses at the Budour northeast wells.

\section{DISCUSSION}

The data presented in this paper demonstrate that commercial exploitation of these microbialite-dominated reservoirs depends on several factors: (1) distribution of primary facies including microbialites, (2) the influence of accommodation history and sediment production on stratigraphic architecture, and (3) the overprint of diagenesis. In this regard, these Precambrian reservoirs are not different from their younger Phanerozoic counterparts. However, at a more detailed level there are some important differences. Significantly, some of the concepts that emerge from analysis of these differences may also be important for exploration of Phanerozoic microbially dominated carbonates formed in restricted marine or lacustrine environments, or immediately after major extinction events (e.g., Late Devonian: Shen and Webb, 2004; Early Triassic: Kershaw et al., 2007).

To start with, we review the stratigraphic controls on reservoir quality that follow more standard patterns driven by accommodation variations. Following that, we discuss those aspects that are most distinctive to the Ara platforms, and which may be relevant to understanding other microbialitedominated carbonates.

\section{Stratigraphic Controls on Reservoir Quality}

The Ara platforms discussed in the current study contain a distinct suite of facies and facies associations that occur in a predictable framework of accommodation variations. Through extensive coring, it has been 
possible to demonstrate the repeatability of these facies and their spatial position with respect to other facies. Though diagenetic factors ultimately impose a strong control on reservoir quality in the Ara stringer play, the primary facies determines exploration-scale distribution of reservoir fairways.

Deeper ramp and downslope mudstones always show poor reservoir quality. Many occurrences of these facies are preserved as limestones, and their neomorphism results in an interlocked crystal mosaic with little or no porosity and permeability. In some cases, these facies are dolomitized; however, this does not improve the quality of a facies that has low initial permeability, especially following compaction. Therefore, it has become critically important in exploration of these carbonates to avoid drilling these deeper ramp and basin environments. With regard to production, the intercalation of fine-grained carbonates has also been recognized to cause partitioning of reservoirs, as in the case of the $\mathrm{A} 4 \mathrm{C}$ platform in the Birba field. Here, mudstones and fine-grained, peloidal packstones accumulated as downdip ramp facies, causing degradation of reservoir-forming crinkly laminite facies (Schröder et al., 2005).

Reservoir performance is enhanced by the presence of shallower water grainstones, thrombolites, and peritidal facies. Generally, these rocks are dolomitized, which is critically important to their high reservoir quality. Dolomitization adds intercrystalline porosity to facies with higher initial porosities. In contrast, facies with very high initial porosities, such as thrombolites, can be susceptible to halite plugging that dramatically lowers porosity and permeability (Schoenherr et al., 2008). Limestones with initially high porosities also show lower reservoir quality due to neomorphic recrystallization.

\section{Lateral Continuity of Reservoir Facies}

The considerable lateral continuity of reservoir facies in the Ara platforms has been confirmed through extensive development and production-related drilling. During early phases of exploration, this was uncertain, perhaps because of the implications of the colloquial term "stringer" as applied to the occurrence of carbonates floating in salt. As used elsewhere, such as in the Zechstein basin, the term stringer denotes thin, often anhydritic units that are interspersed with halite and potash salt deposits, or basinal carbonates with limited reservoir potential (Geluk, 2000). They do not generally contain shallowwater platform facies. In contrast, the Ara stringers are bonafide carbonate platforms with complex differentiation of facies expressed along depositional profiles.

During the initial exploration campaign the prediction of Ara reservoir facies in part depended on comparison to outcrop analogs of age-equivalent carbonates from the Nama Group of Namibia. A number of studies were conducted to determine types of facies substitution along particular depositional and morphologic profiles (cf. Kerans and Tinker, 1999), and the lateral extent of these facies in three dimensions (Adams et al., 2004; DiBenedetto and Grotzinger, 2005; Grotzinger et al., 2005; Johnson and Grotzinger, 2006). In the Nama Group, both ramps and rimmed platforms display facies substitutions involving updip grainstones that pass downdip into broad, spatially extensive tracts of microbial laminites and finely laminated mudstones deposited above and below storm wave base. Trough cross-bedded, coarse grainstones are shown to transition downdip into finer grained grainstones, and then into mudstones or crinkly (microbial) laminites. All sequences have a highstand systems tract dominated by grainstone facies that (1) exhibit minimum variability both laterally and vertically, (2) are uniformly thick, and (3) are laterally continuous over the entire study area (tens of $\mathrm{km}$ in both width and length minimum).

Thrombolite reefs occur as lenticular buildups that often occupy TSTs when accommodation is increasing and sediment flux is reduced. Greater lateral continuity correlates with lower accommodation. This tendency is analogous to what is observed in carbonates of younger age. Generally, in carbonate ramp depositional environments, isolated carbonate buildups develop mostly during late transgressive and early highstand systems tracts when sediment input is reduced (Burchette and Wright, 1992; Dorobek and Bachtel, 2001). Similar patterns are observed for reefal microbialites in the Nama Group (Grotzinger and James, 2000; Adams et al., 2004), and, by inference based on cores, is the case for the Ara Group. The development of lenticular-shaped buildups in deeper settings and tabular-shaped buildups in settings with reduced accommodation has been documented as well 
in the Lower Cretaceous of New Mexico (MurilloMuneton and Dorobek, 2003). Here, aggradational, lenticular, and symmetrical carbonate mud mounds a few meters to tens of meters in size and with a low syndepositional relief $(<5 \mathrm{~m}[<16.4 \mathrm{ft}])$ developed in mud-dominated outer ramp to basinal settings. Tabular buildups with widths up to several hundred

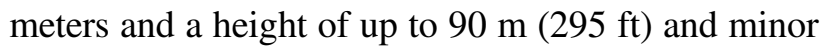
synoptic relief were associated with coarse-grained skeletal fragments indicating higher accumulation rates and shallower water depths. The progressively shallowing Lower Cretaceous carbonate ramp sequence of New Mexico appears quite similar to the terminal Proterozoic Nama Group carbonate ramp system. In a carbonate ramp shoaling sequence the following changes usually occur: (1) buildup morphology changes from lenticular to tabular, (2) syndepositional relief decreases, and (3) the associated grainy facies becomes coarser.

Clearly, accommodation trends and sedimentation rates determine the geometry and dimensions of developing carbonate buildups within carbonate ramp systems. The stratigraphic position of buildups within the framework thus has strong reservoir implications. Within a given TST, a regime of increasing accommodation through time favors the transition from sheet-like biostromal geometries to more isolated patch and pinnacle biohermal geometries. Similarly, increasing spatial accommodation, such as a transect down depositional dip, shows a similar transition from more sheet-like geometries in updip positions to more patchy geometries in downdip positions.

\section{Laminites: What Water Depth?}

One of the most common questions to be addressed in interpreting Ara sedimentology is the inferred water depth of the various laminated facies. This is important since facies distribution significantly influences reservoir quality. Given limited data, as occurred in the early phases of exploration, several Ara laminated facies might be interpreted to be deposited in shallow water, even within peritidal settings. Though peritidal facies are indeed identified to occur in the Ara platforms, there are several facies that represent a relatively deeper environment, probably below wave base. In core, these facies, particularly those with inferred microbial influences, may be difficult to distinguish without additional context.

Part of the problem is the age of these rocks; prior to the advent of widespread bioturbation most Precambrian normal marine carbonates are laminated (Grotzinger, 1988; Grotzinger and James, 2000). This generalization would exclude coarse-grained carbonates, slope-related sediment gravity-flow deposits (e.g., debris flows), and thrombolites, which by definition are clotted not laminated (Kennard and James, 1986). However, in both outcrop and core it is remarkable how many facies are laminated. In essence, all fine-grained carbonates deposited from suspension will be laminated. The alternation of fine sediments (carbonates, silica, and shale) and pelagically derived organics will impart a fine mm-scale lamination. Consider, for example, the origin of diatomites formed during the Miocene and more recently in the Santa Barbara basin and its precursors (Grimm and Lange, 1996). In another example, deeper water carbonates in the Permian Zechstein basin are composed of fetid, finely laminated carbonates in which muddy carbonate laminae alternate at the mm-scale with organic-rich laminae (Geluk, 2000). In the Zechstein basin, water depths are inferred to have been many tens of meters to up to $200 \mathrm{~m}(656 \mathrm{ft})$; in the Santa Barbara basin, water depths are hundreds of meters to over $1 \mathrm{~km}$ (0.62 mi). In both cases, pelagic processes dominated the formation of lamination.

Pelagic processes that contribute to laminated sediments are supplemented or even dominated by benthic processes in many ancient laminites. Above the photic zone, the seafloor in many cases would have been covered with a microbial mat not normally present in Phanerozoic carbonate environments. This would have resulted from the absence of invertebrates that would have grazed the mat, burrowed the mat, and/or competed with the mat for substrate space. These organisms evolved in late Precambrian (Ediacaran) time and exerted some influence, though it is not visibly important in the rock record, with the exception of thrombolites that probably derive a significant component of their clotted texture from the participation of higher algae in mat development (Feldmann and McKenzie, 1997, 1998; Grotzinger and James, 2000; Grotzinger et al., 2005). Nevertheless, the widespread development of benthic mats in Precambrian time would have 
ensured that lagoons as well as deeper ramp settings developed microbial laminite facies in addition to their usual position in peritidal environments, as is common in the Phanerozoic. Indeed, the presence of microbial laminite facies in Phanerozoic carbonates is classically regarded as evidence of a peritidal environment (Aitken, 1967; Koerschner and Read, 1989). Therefore, the interpretation of millimeter-scale lamination in cores could become problematic in terms of assigning a particular water depth or paleogeographic interpretation. This may well also apply to Phanerozoic lacustrine depositional systems. where microbialites - and associated laminites_may be important.

There are several approaches to aid in the interpretation of these laminites. As discussed earlier, the use of facies association is critically important as this provides additional context. Furthermore, the facies itself may be defined by the presence or absence of particular features, which are diagnostic of, say, episodically exposed tidal flat; for example, mud chips, mud cracks, and upward-deflected laminae adjacent to mudcracks. However, in permanently subaqueous settings, such features will be absent and distinction of water depth and paleogeographic position more difficult. In this case, facies interpretation will depend on the independently established stratigraphic framework that shows lateral transitions in depth gradients. In addition, use of analogs is important as we will now discuss.

\section{Crinkly Laminites}

Stratigraphic and sedimentologic evidence in the Ara Group indicates that crinkly laminites are deeper water facies, most likely the time equivalent of updip pustular laminites, thrombolites, and grainstones. This interpretation can be supported with reference to outcrop analogs. In the Nama Group of Namibia, changes in facies as a function of water depth and paleogeographic location can be demonstrated through lateral tracing of beds in regions of superb outcrop (Adams et al., 2004, 2005; DiBenedetto and Grotzinger, 2005; Grotzinger et al., 2005; Johnson and Grotzinger, 2006). For example, facies transitions in the Hoogland ramp include updip coarse grainstones that grade downdip into finer grainstones, and then into broad, spatially extensive tracts of microbial laminites and finely laminated mudstones
(DiBenedetto and Grotzinger, 2005). The microbial laminites show textures that are similar to the pustular laminites and crinkly laminites of the Ara Group. At the bed scale, Hoogland facies patterns were controlled by upward growth of microbial mats, fallout of suspended sediment, and lateral transport of sediment through high-bed-shear stress created by strong storm-induced flows. At the scale of individual laminae, roughening of the seafloor through heterogeneous trapping and binding by microbial mats was balanced by smoothing of the seafloor through accumulation of loose sediment to fill the millimeter- to centimeter-scale nooks and crannies within the upward-propagating mat. Below wave base, this process generates facies tracts that cover very broad areas, much greater than tidal flats. In a low-energy setting, it is possible that much of the subtidal seafloor could be covered with microbial mats that could form laminites with favorable reservoir properties, such as occurred in the crinkly laminites of the A4 platform in the Ara Group (Schröder et al., 2004). The same relationships hold for other ramps in the Nama Group (e.g., Omkyk Member, Adams et al., 2005) as well as the $300 \mathrm{~m}$ (984 ft) thick isolated platform at Dreidoornvlakte (Adams et al., 2004). In all cases, crinkly or other microbial laminites form extensive subtidal accumulations of microbially generated facies. The important point is that some of these laminites show rougher laminae boundaries, which are interpreted to represent benthic mats, whereas laminites with smooth laminae boundaries may represent mostly pelagic accumulation of organic matter, though benthic mats cannot be ruled out. As discussed early in this paper, it is possible that crinkly laminites in part represent former mats composed of chemoautotrophic bacteria rather than photosynthetic bacteria.

\section{SUMMARY}

The Ediacaran-Cambrian Ara Group in the SOSB contains at least five stratigraphically distinct reservoir-bearing carbonate platforms, bounded by salt, and concentrated in two spatially separated domains: the Harweel cluster and the Birba cluster. Each platform has been disrupted by halokinesis, but 
stratigraphic data indicate that these separate blocks once formed laterally continuous platforms. Reconstruction of blocks indicates that these isolated platforms nucleated on flooded salt deposits. Internal facies show strong platform-to-basin differentation. Exploration-related drilling has shown that basinal deposits are non-porous mudstones, whereas platform deposits comprise a variety of different reservoir facies, including both conventional grainstones and packstones, in addition to unconventional microbialites.

Based on field development drilling, the Ara platforms show facies differentiation according to spatial and temporal variations in accommodation space. Early salt movements coupled with subsalt tectonic offsets helped localize platform nucleation and growth, whereas relative sea-level oscillations promoted stratigraphic stacking patterns of repetitive facies, including those with favorable reservoir attributes. Deeper ramp, slope, and basinal facies include massive mudstones, thick-laminated to thin-bedded mudstones, minor carbonate turbidites, and rare shelfderived breccias with muddy matrix support. None of these facies exhibit favorable reservoir qualities and exploration strategies attempt to predict and avoid them. In some platforms, especially the A4 platform of the Birba cluster, crinkly laminites form a deeper ramp facies with good reservoir quality when dolomitized. In all platforms, mudstones or crinkly laminites may pass updip into shallower ramp pustular laminites that may have good reservoir properties, including dolomitization. These pass further updip into shallow subtidal thrombolites that may have very high initial porosities $(>50 \%)$, although later salt plugging can dramatically reduce their porosity. Peloidal packstone-grainstone, hummocky cross-stratified peloidintraclast grainstone, and trough cross-bedded coarse intraclast grainstone form excellent reservoirs and represent a suite of progressively shallow water facies of more conventional origin. Decreasing accommodation tends to favor increasing lateral continuity in both thrombolites as well as grainstones. Grainstones can be amalgamated across sequence boundaries forming in late highstand to early TSTs.

Platform carbonates contain at least four major textures of microbially influenced origin: thrombolites, pustular laminites, crinkly laminites, and tufted laminites. Thrombolites are massive, have clotted textures with cm-scale pore networks, and form discrete buildups. Pustular laminites are crudely stratified, have $\mathrm{mm}$-scale clotted textures and pore networks, and form aerially extensive subtidal sheets that may develop between thrombolite buildups and extend downdip from thrombolite buildups. Crinkly laminites are well stratified, have mm-scale fenestral textures and pore networks, and form laterally extensive subtidal sheets that generally extend downdip of pustular laminites. Tufted laminites are well stratified, have mm- to $\mathrm{cm}$-scale tufted textures with mm-scale pore networks, and form areally restricted sheets within peritidal facies belts.

With the exception of crinkly laminites, which may have a significant pelagic contribution to their textures, the other microbially influenced facies all represent significant benthic primary productivity of microbial communities. The formation of these textures involved a balance between microbial sediment production, including organics, and inorganic fallout of suspended carbonate muds. Primary microbial growth as well as diagenetic remineralization of organics produced complex pore systems that differ in size and geometry depending on facies and the extent of overprinting dolomitization. These microbially influenced facies form laterally extensive sheets that, in some cases, may have covered vast tracts of the subtidal ramp depositional surface. Although common in Precambrian carbonates, such widespread tracts do not occur in modern carbonate environments or in typical Phanerozoic marine carbonates. However, Ara facies types and dimensions may have relevance to understanding Phanerozoic microbially influenced reservoir facies formed in restricted marine basins, lacustrine settings, or during times of faunal recovery following mass extinction events.

\section{REFERENCES CITED}

Adams, E. W., S. Schröder, J. P. Grotzinger, and D. S. McCormick, 2004, Digital reconstruction and stratigraphic evolution of a microbial-dominated, isolated carbonate platform (terminal Proterozoic, Nama Group, Namibia): Journal of Sedimentary Research, v. 74, p. 479-497.

Adams, E. W., J. P. Grotzinger, W. A. Watters, S. Schröder, D. S. McCormick, and H. A. Al-Siyabi, 2005, Digital characterization of thrombolite-stromatolite reef distribution in a 
carbonate ramp system (terminal Proterozoic, Nama Group, Namibia): AAPG Bulletin, v. 89, no. 10, p. 1293-1318.

Aitken, J. D., 1967, Classification and environmental significance of cryptalgal limestones and dolomites, with illustrations from the Cambrian and Ordovician of southwestern Alberta: Journal of Sedimentary Petrology, v. 37, no. 4, p. $1163-1178$.

Al-Marjeby, A., and D. Nash, 1986, A summary of the geology and oil habitat of the Eastern Flank Hydrocarbon Province of South Oman: Marine and Petroleum Geology, v. 3, no. 4, p. 306-314.

Al-Siyabi, H. A., 2005, Exploration history of the Ara intrasalt carbonate stringers in the South Oman Salt Basin: Geoarabia, v. 10, no. 4, p. 39-72.

Allen, P. A., 2007, The Huqf supergroup of Oman: Basin development and context for neoproterozoic glaciation: Earth-Science Reviews, v. 84, no. 3-4, p. 139-185.

Amthor, J. E., J. P. Grotzinger, S. Schroeder, and B. C. Schreiber, 2002, Tectonically-driven evaporite-carbonate transitions in a Precambrian/Cambrian saline giant: Ara Salt Basin of South Oman (abs.): 2002 AAPG Annual Convention, v. 11, A6.

Amthor, J. E., J. P. Grotzinger, S. Schröder, S. A. Bowring, J. Ramezani, M. W. Martin, and A. Matter, 2003, Extinction of Cloudina and Namacalathus at the PrecambrianCambrian boundary in Oman: Geology, v. 31, no. 5, p. 431-434.

Amthor, J. E., K. Ramseyer, T. Faulkner, and P. Lucas, 2005, Stratigraphy and sedimentology of a chert reservoir at the Precambrian-Cambrian boundary: The Al Shomou Silicilyte, South Oman Salt Basin: Geoarabia, v. 10, no. 3, p. 89-122.

Anderson, R. Y., W. E. Dean, D. W. Kirkland, and H. I. Snider, 1972, Permian Castile varved evaporite sequence, West Texas and New Mexico: Geological Society of America Bulletin, v. 83, no. 1, p. 59-86.

Ball, M. M., E. A. Shinn, and K. W. Stockman, 1967, The geologic effects of Hurricane Donna in south Florida: Journal of Geology, v. 75, no. 5, p. 583-597.

Bergmann, K., 2013, Constraints on the carbon cycle and climate during the early evolution of animals, Ph.D. thesis, California Institute of Technology, Pasadena, California, $368 \mathrm{p}$.

Bergmann, K., J. P. Grotzinger, and M. Osburn, 2012, Telling time in microbial carbonates: A case study from the Latest Precambrian, Sultanate of Oman, 2012 AAPG Convention and Exhibition, Long Beach, California, accessed May 21, 2014, http://www.searchanddiscovery.com/abstracts/html/ 2012/90142ace/abstracts/bergmann.htm.

Bosak, T., B. Liang, M. S. Sim, and A. P. Petroff, 2009, Morphological record of oxygenic photosynthesis in conical stromatolites: Proceedings of the National Academy of Sciences, v. 106, p. 10939-10943.

Bowring, S. A., J. P. Grotzinger, D. J. Condon, J. Ramezani, M. J. Newall, and P. A. Allen, 2007, Geochronologic constraints on the chronostratigraphic framework of the neoproterozoic Huqf Supergroup, Sultanate of Oman: American Journal of Science, v. 307, no. 10, p. 1097-1145.

Burchette, T. P., and V. P. Wright, 1992, Carbonate ramp depositional systems: Sedimentary Geology, v. 79, p. 3-57.
Burne, R. V., and L. S. Moore, 1987, Microbialites; organosedimentary deposits of benthic microbial communities: Palaios, v. 2, p. 241-254.

Chafetz, H. S., and C. Buczynski, 1992, Bacterially induced lithification of microbial mats: Palaios, v. 7, p. 277-293.

Cozzi, A., P. A. Allen, and J. P. Grotzinger, 2004, Understanding carbonate ramp dynamics using delta $\mathrm{C}-13$ profiles: Examples from the Neoproterozoic Buah Formation of Oman: Terra Nova, v. 16, no. 2, p. 62-67.

Davies, P. J., and J. F. Marshall, 1986, Halimeda bioherms-low energy reefs, northern Great Barrier Reef: Proceedings of the Fifth International Coral Reef Symposium (Tahiti, 1985), v. 5, p. 1-7.

de Raaf, J. F. M., J. R. Boersma, and A. V. Gelder, 1977, Wavegenerated structures and sequences from a shallow marine succession, Lower Carboniferous, County Cork, Ireland: Sedimentology, v. 24, no. 4, p. 451-483.

DiBenedetto, S., and J. Grotzinger, 2005, Geomorphic evolution of a storm-dominated carbonate ramp (ca. $549 \mathrm{Ma}$ ), Nama Group, Namibia: Geological Magazine, v. 142, no. 5, p. 583-604.

Dorobek, S. L., and S. L. Bachtel, 2001, Supply of allochthonous sediment and its effects on development of carbonate mud mounds, Mississippian Lake Valley Formation, Sacramento Mountains, south-central New Mexico: Journal of Sedimentary Research, v. 71, no. 6, p. 1003-1016.

Dott, R. H., Jr., and J. Bourgeois, 1982, Hummocky stratification: Significance of its variable bedding sequences: Geological Society of America Bulletin, v. 93, no. 8, p. 663-680.

Esteban, M. C., 1976, Vadose pisolite and caliche: AAPG Bulletin, v. 60, no. 11, p. 2048-2057.

Feldmann, M., and J. A. McKenzie, 1997, Messinian stromatolite-thrombolite associations, Santa Pola, Spain: An analogue for the Paleozoic?: Sedimentology, v. 44, no. 5, p. 893-914.

Feldmann, M., and J. McKenzie, 1998, Stromatolite-thrombolite associations in a modern environment, Lee Stocking Island, Bahamas: Palaios, v. 13, no. 2, p. 201-212.

Fike, D. A., 2007, Carbon and sulfur isotopic constraints on Ediacaran biogeochemical processes, Huqf Supergroup, Sultanate of Oman: Ph.D. thesis, Massachusetts Institute of Technology, Cambridge, Massachusetts, $231 \mathrm{p}$.

Fike, D. A., and J. P. Grotzinger, 2008, A paired sulfate-pyrite delta S-34 approach to understanding the evolution of the Ediacaran-Cambrian sulfur cycle: Geochimica Et Cosmochimica Acta, v. 72, no. 11, p. 2636-2648.

Forbes, G. A., H. S. M. Jansen, and J. Schreurs, 2010, Lexicon of Oman subsurface stratigraphy: Reference guide to the stratigraphy of Oman's hydrocarbon basins: GeoArabia Special Publication 5, Gulf PetroLink, Bahrain, 371 p.

Gallardo, V. A., 1977, Large benthic microbial communities in sulphide biota under Peru-Chile subsurface countercurrent: Nature, v. 268, no. 5618, p. 331-332.

Geluk, , M. C., 2000, Late Permian (Zechstein) carbonate-facies maps, the Netherlands. Geologie en Mijnbouw/ Netherlands: Journal of Geosciences, v. 79, no. 1, p. 17-27.

Gold, S. E. P., 2010, Stratigraphy and correlation of the Sarab Formation, Al Huqf area, with the subsurface Ara Group play systems of Oman: Ph.D. thesis, Trinity College, Dublin, 187 p. 
Gorin, G. E., L. G. Racz, and M. R. Walter, 1982, Late Precambrian-Cambrian sediments of Huqf Group, Sultanate of Oman: AAPG Bulletin, v. 66, no. 12, p. 2609-2627.

Grant, S. W. F., A. H. Knoll, and G. J. B. Germs, 1991, Probable calcified metaphytes in the latest Proterozoic Nama Group, Namibia: Origin, diagenesis, and implications: Journal of Paleontology, v. 65, p. 1-18.

Grimm, K., and C. Lange, 1996, Biological forcing of hemipelagic sedimentary laminae: Evidence from ODP Site 893, Santa Barbara basin, California: Journal of Sedimentary Research, v. 66, no. 3, p. 613-624.

Grosjean, E., G. D. Love, C. Stalview, D. A. Fike, and R. E. Summons, 2009, Origin of petroleum in the Neoproterozoic-Cambrian South Oman Salt Basin: Organic Geochemistry, v. 40, no. 1, p. 87-110.

Grotzinger, J. P., 1988, Introduction to Precambrian reefs, in H. Geldsetzer, N. P. James, and G. Tebbutt, eds., ReefsCanada and Adjacent Areas: Canadian Society of Petroleum Geologists, Memoir 13, p. 9-12.

Grotzinger, J. P., 1989, Facies and evolution of Precambrian carbonate depositional systems: Emergence of the modern platform archetype: Controls on Carbonate Platform and Basin Development, v. 44, no. 6599, p. 79-106.

Grotzinger, J. P., 2009, A $\delta^{34} \mathrm{~S}\left(\mathrm{SO}_{4}\right)$ approach to reconstructing biogenic pyrite burial in carbonate-evaporite basins: an example from the Ara Group, Sultanate of Oman: Geology, v. 38, no. 5, p. 371-374.

Grotzinger, J., E. W. Adams, and S. Schröder, 2005, Microbialmetazoan reefs of the terminal Proterozoic Nama Group (ca. 550-543 Ma), Namibia: Geological Magazine, v. 142, no. 5 , p. 499-517.

Grotzinger, J. P., H. A. Al-Siyabi, R. Al-Hashmi, and A. Cozzi, 2002, New model for tectonic evolution of NeoproterozoicCambrian Huqf Supergroup basins, Oman: GeoArabia (Manama), v. 7, no. 2, p. 241.

Grotzinger, J. P., and N. P. James, 2000, Precambrian carbonates: evolution of understanding: Carbonate Sedimentation and Diagenesis in the Evolving Precambrian World, SEPM Special Publication, v. 67, p. 3-20.

Grotzinger, J. P., and A. H. Knoll, 1999, Stromatolites in Precambrian carbonates: Evolutionary mileposts or environmental dipsticks?: Annual Review of Earth and Planetary Sciences, v. 27, p. 313-358.

Grotzinger, J. P., and D. H. Rothman, 1996, An abiotic model for stromatolite morphogenesis: Nature, v. 383, no. 6599, p. 423-425.

Haines, P. W., 1988, Storm-dominated mixed carbonate/siliciclastic shelf sequence displaying cycles of hummocky cross-stratification, late Proterozoic Wonoka Formation, South Australia: Sedimentary Geology, v. 58, no. 2-4, p. 237-254.

Hardie, L. A., 1977, Sedimentation on the modern carbonate tidal flats of northwest Andros Island, Bahamas: Baltimore, The Johns Hopkins University Press, 202 p.

Harris, P. M., 2010, Delineating and quantifying depositional facies patterns in carbonate reservoirs: Insight from modern analogs: AAPG Bulletin, v. 94, no. 1, p. 61-86.

Hofmann, H. J., and E. W. Mountjoy, 2001, NamacalathusCloudina assemblage in Neoproterozoic Miette Group
(Byng Formation), British Columbia: Canada's oldest shelly fossils: Geology, v. 29, no. 2, p. 1091-1094.

Immerz, P., W. H. Oterdom, and M. E. Tonbary, 2000, The Huqf/ Haima hydrocarbon system of Oman and the terminal phase of the Pan-African Orogeny: Evaporite deposition in a compressive setting: GeoArabia (Manama), v. 5, no. 1, p. 113-114.

Johnson, J., and J. P. Grotzinger, 2006, Affect of sedimentation on stromatolite reef growth and morphology, Ediacaran Omkyk Member (Nama Group), Namibia: South African Journal of Geology, v. 109, no. 1-2, p. 87-96.

Kellerhals, P., and A. Matter, 2003, Facies analysis of a glaciomarine sequence, the Neoproterozoic Mirbat Sandstone Formation, Sultanate of Oman: Eclogae Geologicae Helvetiae, v. 96, no. 1, p. 49-70.

Kennard, J. M., and N. P. James, 1986, Thrombolites and stromatolites: Two distinct types of microbial structures: Palaios, v. 1 , no. 5 , p. 492-503.

Kerans, C., and S. W. Tinker, 1999, Extrinsic controls on development of the Capitan reef complex, in A. H. Saller, P. M. Harris, B. L. Kirkland, and S. J. Mazzullo, eds., Geologic Framework of the Capitan Reef: Society of Economic Paleontologists and Mineralogists, Special Publication 65, p. 15-36.

Kershaw, S., Y. Li, S. Crasquin-Soleau, Q. Feng, X. Mu, P.-Y. Collin, A. Reynolds, and L. Guo, 2007, Earliest Triassic microbialites in the South China block and other areas: Controls on their growth and distribution: Facies, v. 53, p. 409-425.

Koerschner, W. F., III, and J. F. Read, 1989, Field and modelling studies of Cambrian carbonate cycles, Virginia Appalachians: Journal of Sedimentary Petrology, v. 59, no. 5, p. 654-687.

Loosveld, R. J. H., A. Bell, and J. J. M. Terken, 1996, The tectonic evolution of interior Oman: Geoarabia, v. 1, no. 1, p. $28-51$.

Love, G. D., E. Grosjean, C. Stalvies, D. A. Fike, J. P. Grotzinger, A. S. Bradley, A. E. Kelly, M. Bhatia, W. Meredith, C. E. Snape, S. A. Bowring, D. J. Condon, and R. E. Summons, 2009, Fossil steroids record the appearance of Demospongiae during the Cryogenian period: Nature, v. 457 , no. 7230 , p. $718-722$.

Mattes, B. W., and S. C. Morris, 1990, Carbonate Evaporite Deposition in the Late Precambrian-Early Cambrian Ara Formation of Southern Oman: Geology and Tectonics of the Oman Region, v. 49, p. 617-636.

Mercolli, I., A. P. Briner, R. Frei, R. Schonberg, T. F. Nagler, J. Kramers, and T. Peters, 2006, Lithostratigraphy and geochronology of the Neoproterozoic crystalline basement of Salalah, Dhofar, Sultanate of Oman: Precambrian Research, v. 145, no. 3-4, p. 182-206.

Morton, D. M., 1959, The geology of Oman: 5th World Petroleum Congress, New York, section 1, paper 14, p. 277-294.

Mount, J. F., and D. Kidder, 1993, Combined flow origin of edgewise intraclast conglomerates: Sellick Hill Formation (Lower Cambrian), South Australia: Sedimentology, v. 40, no. 2, p. 315-329.

Murillo-Muneton, G., and S. Dorobek, 2003, Controls on the evolution of carbonate mud mounds in the lower Cupido 
Formation (Lower Cretaceous), northeastern Mexico: Journal of Sedimentary Research, v. 73, no. 6, p. 869-886.

Osburn, M., J. Grotzinger, and K. Bergmann, 2014, Facies, Stratigraphy, and evolution of a Middle Ediacaran carbonate ramp: Khufai Formation, Sultanate of Oman: AAPG Bulletin, v. 98, no. 8, p. 1631-1667.

Pope, M., and J. P. Grotzinger, 2001, Controls on fabric development and morphology of tufa and stromatolites, uppermost Pethei Group (1.8 Ga), Great Slave Lake, northwest Canada, in J. P. Grotzinger and N. P. James, eds., Precambrian Carbonates: SEPM Special Publication 67, p. 103-121.

Pope, M., J. Grotzinger, and B. C. Schreiber, 1999, Evaporitic subtidal stromatolites sroduced by in situ precipitation: Textures, facies associations, and temporal significance: Journal of Sedimentary Research, v. 70, no. 5, p. 1139-1151.

Pratt, B. R., N. P. James, and C. A. Cowan, 1992, Peritidal carbonates, in R. G. Walker and N. P. James, eds., Facies models: Response to sea level change: St. John's, Newfoundland, Geological Association of Canada, p. 303-322.

Read, J. F., 1985, Carbonate platform facies models: AAPG Bulletin, v. 69, no. 1, p. 1-21.

Riding, R., 2000, Microbial carbonates: The geological record of calcified bacterial-algal mats and biofilms: Sedimentology, v. 47, Suppl. 1, p. 179-214.

Robbins, L. L., and P. L. Blackwelder, 1992, Biochemical and ultrastructural evidence for the origin of whitings: Abiologically induced calcium carbonate precipitation mechanism: Geology, v. 20, no. 5, p. 464-468.

Roehl, P. O., and P. W. Choquette, eds., 1985, Carbonate Petroleum Reservoirs: New York, Springer-Verlag, 622 p.

Sarg, J. F., 2001, The sequence stratigraphy, sedimentology, and economic importance of evaporite-carbonate transitions: A review: Sedimentary Geology, v. 140, no. 1-2, p. 9-42.

Schoenherr, J., L. Reuning, P. Kukla, R. Littke, J. Urai, M. Seimann, and Z. Rawahi, 2008, Halite cementation and carbonate diagenesis of intra-salt reservoirs from the Late Neoproterozoic to Early Cambrian Ara Group (South Oman Salt Basin): Sedimentology, v. 56, no. 2, p. 567-589.

Schröder, S., J. P. Grotzinger, J. E. Amthor, and A. Matter, 2005, Carbonate deposition and hydrocarbon reservoir development at the Precambrian-Cambrian boundary: The Ara Group in South Oman: Sedimentary Geology, v. 180, no. 1-2, p. 1-28.

Schröder, S., B. C. Schreiber, J. E. Amthor, and A. Matter, 2003, A depositional model for the terminal Neoproterozoic Early Cambrian Ara Group evaporites in south Oman: Sedimentology, v. 50, no. 5, p. 879-898.

Schröder, S., B. C. Schreiber, J. E. Amthor, and A. Matter, 2004, Stratigraphy and environmental conditions of the terminal Neoproterozoic-Cambrian period in Oman: Evidence from sulphur isotopes: Journal of the Geological Society, v. 161, no. 3, p. 489-499.

Schulz, H. N., T. Brinkhoff, T. G. Ferdelman, M. H. Mariné, A. Teske, and B. B. Jørgensen, 1999, Dense populations of a giant sulfur bacterium in Namibian shelf sediments: Science, v. 284, p. 493-495.

Shen, J., and G. E. Webb, 2004, Famennian (Upper Devonian) stromatolite reefs at Shatang, Guilin, Guangxi, South China: Sedimentary Geology, v. 170, p. 63-84.

Shinn, E. A., R. P. Steinen, B. H. Lidz, and P. K. Swart, 1989, Whitings, a sedimentologic dilemma: Journal of Sedimentary Research, v. 59, no. 1, p. 147-161.

van Gemerden, H., 1993, Microbial mats: A joint venture: Marine Geology, v. 113, no. 1-2, p. 3-25.

Walter, M. R., ed., 1976, Stromatolites: Developments in Sedimentology, v. 20, Amsterdam, Elsevier, 790 p.

Wright, V. P., A. C. Ries, and S. G. Munn, 1990, Intraplatformal basin-fill deposits from the Infracambrian Huqf Group, east Central Oman: Geological Society, London, Special Publications, v. 49, p. 601-616. 